Article

\title{
Assessment of Groundwater Drought in the Mangyeong River Basin, Korea
}

\author{
Jae Min Lee ${ }^{\mathbb{D}}$, Jong Hoon Park, Euijin Chung and Nam C. Woo *(i) \\ Department of Earth System Sciences, Yonsei University, Seoul 03722, Korea; \\ leejm03@gmail.com (J.M.L.); pjhwhdgns@yonsei.ac.kr (J.H.P.); sapari93@hanmail.net (E.C.) \\ * Correspondence: ncwoo@yonsei.ac.kr; Tel.: +82-2-2123-2674
}

Received: 23 January 2018; Accepted: 9 March 2018; Published: 15 March 2018

\begin{abstract}
When groundwater drought occurs, baseflow discharges to surface-water bodies will be reduced and then domestic and agricultural water usage becomes at risk of insufficient supply. Thus, in this study, several methods for groundwater drought assessment were tested with long-term monitoring water-level data in the study area to preserve groundwater sustainability from drought, principally caused by reduced precipitation and propagated through agricultural drought and groundwater drought. Because of the Monsoon climate on the Korean Peninsula, the groundwater storage (or water-level) is secured until the end of summer, then falls by natural discharge during the dry seasons of autumn, winter and the following spring. Thus, the rainfall in the wet season seems to mainly influence groundwater storage until the spring of the following year. As the groundwater level (GWL) declines due to natural drainage and the use of agricultural water increases by the end of the dry season (October-May), the GWL will become lowered below the critical level. Below this level, sufficient water supply is not secured. Using the Standardized Precipitation Index (SPI), threshold method and $95 \%$ probability occurrence method, drought detection and the frequency of drought are compared. Groundwater drought using the threshold method results in more frequent occurrence than using the SPI method. The 95\% occurrence method responds to severe drought but it also has weakness in missing the man-induced GWL decline in every spring season. For groundwater drought assessment, an appropriate drought index should be utilized according to climatic conditions and catchment characteristics. In the study area, variations of the both natural and anthropogenic effects are mixed and the threshold method is more suitable as a measure for preventing water resources shortage.
\end{abstract}

Keywords: groundwater drought; long-term monitoring; sustainability; threshold method; baseflow; water resources

\section{Introduction}

Drought is a natural hazard that can cause significant environmental (e.g., aquatic ecosystem, water quantity and quality, wildfire) and socio-economic losses. The phenomenon can be prolonged and prediction is difficult. Decreasing stream discharge and increasing the levels of sediments and nutrients can lead to a deterioration of water quality [1,2]. Depending on the drought severity, changes in discharge and groundwater-surface water interactions may result in stream water quality changes [3]. A dramatic increase in the demand for water supply has aggravated the impacts of drought in some developing countries.

Drought can be subdivided into four categories: meteorological drought, agricultural drought, hydrological drought (i.e., groundwater and surface water including spring, lake, stream flow, etc.) and socio-economic drought $[4,5]$. This classification is based on the propagation of the impact of drought throughout the hydrological cycle. For example, meteorological drought occurs due to low 
precipitation, causing agricultural drought as less water is available to soil and farmland. Subsequently, the reduced groundwater recharge from the land surface results in a decline in the groundwater head, eventually causing decreases in baseflow following stream discharges. Decreased or even limited water supply could have a significant impact on the sustainability of a society in terms of economic development and social stability. Recently, the eco-drought concept has been proposed as a holistic approach to assess the impact of water shortages on water resources, natural ecosystems and human livelihoods (USGS, http:/ /nccwsc.usgs.gov).

Many approaches using indices or indicators have been proposed to estimate and predict the different types of droughts, including:

- Meteorological drought using the Standardized Precipitation Index (SPI, [6]) and Palmer Drought Severity Index (PDSI, [7])

- Agricultural drought using the Crop Moisture Index (CMI, [8]) and the Normalized Difference Vegetation Index (NDVI, [9])

- Hydrological drought including groundwater and surface water using the Surface Water Supply Index (SWSI, [10])

- Socio-economic/environmental (ecological) drought

The most commonly used SPI is analyzed using only precipitation data as input data and the index has a variability according to past data [6]. The SWSI is estimated using data including precipitation, snowmelt amount, stream flow and storage of reservoir but there is a limit in watershed comparisons [10]. The PDSI method is effective in estimating drought that leads to the decrease of groundwater recharge because it estimates drought using precipitation, temperature and the available water capacity of the soil $[7,11]$. However, the timing of drought may be delayed and accuracy may be reduced in mountainous areas or extreme climate conditions $[7,11]$.

The reasons for the occurrence of droughts are complex and have yet to be clearly defined. Meteorological drought is still difficult to predict due to the spatio-temporal irregularities (non-linearity) of rainfall characteristics. However, unlike meteorological phenomena, which have a large discontinuity, groundwater acting as an intermediate medium to surface water is relatively slow in moving and is relatively less sensitive to changes in external factors [12]. Human activities and artificial construction can affect the groundwater system (e.g., recharge, flow paths, water quality [13-15]); however, if the anthropogenic influence is not significant, the groundwater level (GWL) displays a periodicity, such as daily, seasonal, or annual change [16-19], in addition, GWLs can also response to longer teleconnections and climate variability at multiannual, decadal, or longer time scales [20]. It experiences long-term trends of several hours to several months, depending on the depth and aquifer characteristics. Therefore, the depletion of groundwater during drought events is slow and continuous [21].

In addition, the influence or the propagation of a hydrological drought is dependent on the catchment characteristics [22]. At the watershed scale, the impact of a drought is rapid and easy to observe in recharge areas (e.g., mountains) but is relatively minimal in discharge areas [12]. Water level changes due to drought are greater in the recharge/upstream areas than in the discharge/downstream areas. Zhang et al. [23] conducted an analysis of the upstream and downstream drought impacts in a regulated river (reservoir regulation) and showed that the effect of drought was small in the downstream area. In the dry season, most of the river flow depends on the groundwater baseflow [24,25]. Thus, in the long-term, groundwater depletion could decrease the amount of baseflow discharge to surface water body, agricultural water supply and have a significant influence on the health of groundwater-dependent ecosystems (GDEs) [26,27].

In the evaluation of groundwater drought, a decrease in the GWL caused by both natural and human-induced processes is basically defined as a groundwater drought, although it is difficult to estimate the total amount of water available; instead, the concept of storage deficiency has been adopted [28,29]. Van Loon et al. [30] reported that groundwater drought can be aggravated beyond 
the natural situation by human activities (e.g., irrigation, abstraction, land use and dam building). Mishra and Singh [31] reported that some groundwater data have been or can be used to define or calculate groundwater drought, with groundwater storage or recharge [32] or discharge [33]. Several indices for groundwater drought assessment have been proposed, including the standardized groundwater level index (SGI, [21,34]) and streamflow drought index (SDI, [35,36]), which is based on the standardized precipitation index (SPI, [6]). However, these methods require long-term data (of at least 30 years), particularly the SPI method. In this study, the data only covered a period of 10 years and the SPI was therefore not applied.

There was an extreme drought on the Korean Peninsula in 2008 and droughts have occurred every year since 2012 (NDIAC, http:/ / drought.kwater.or.kr). Subsequently, there is an urgent need for measures that can reduce the risk of drought disaster and mitigate the drought impacts on water resources and the socio-economic conditions. In a groundwater system, although the prediction of drought may be impossible, the impacts of a drought on groundwater storage and stream discharge can be estimated from the relationship between precipitation and GWL in a specific area. This relationship is based on the semi-steady flow characteristics of groundwater. Furthermore, this estimation can be applied at a regional scale in areas with distributed monitoring wells. Based on the estimation, various policies for water resource management can be implemented where appropriate, according to the severity of the likely impact.

Therefore, the purpose of this study was to test a method for evaluating groundwater drought at the catchment scale in the Mangyeong River Basin, located in the southwestern part of the Korean peninsula. The river basin covers the Honam Plain, which is the most important agricultural area in Korea. Of course, forests in the rural area are developed with urban and industrial complexes, following recent industrialization and developments [37]. This area depends on groundwater resources as a major water-supply source. Since 2008, however, droughts have occurred and thus sustainable use of groundwater resources is required. The results of this study will enable better groundwater drought assessment for water resource management, with consideration of the threshold value and baseflow.

\section{Study Area}

The Mangyeong River Basin is located within the Geum River Basin in the middle of the Korean Peninsula (i.e., between $35^{\circ} 37^{\prime}$ to $36^{\circ} 6^{\prime} \mathrm{N}$ and $126^{\circ} 48^{\prime}$ to $127^{\circ} 21^{\prime}$ E). The area of the Mangyeong River Basin is around $1600.63 \mathrm{~km}^{2}$ and the basin is divided into 13 unit sub-basins ([37], Figure 1). Four national rivers are included in the catchment and population of the area is approximately 1 million. Mean annual precipitation for recent 30 years (1985-2014) was about $1275 \mathrm{~mm}$, the average elevation is $124(\mathrm{EL}, \mathrm{m})$ with maximum elevation of $1112 \mathrm{~m}$ and the average slope is $25 \%$ [37]. 


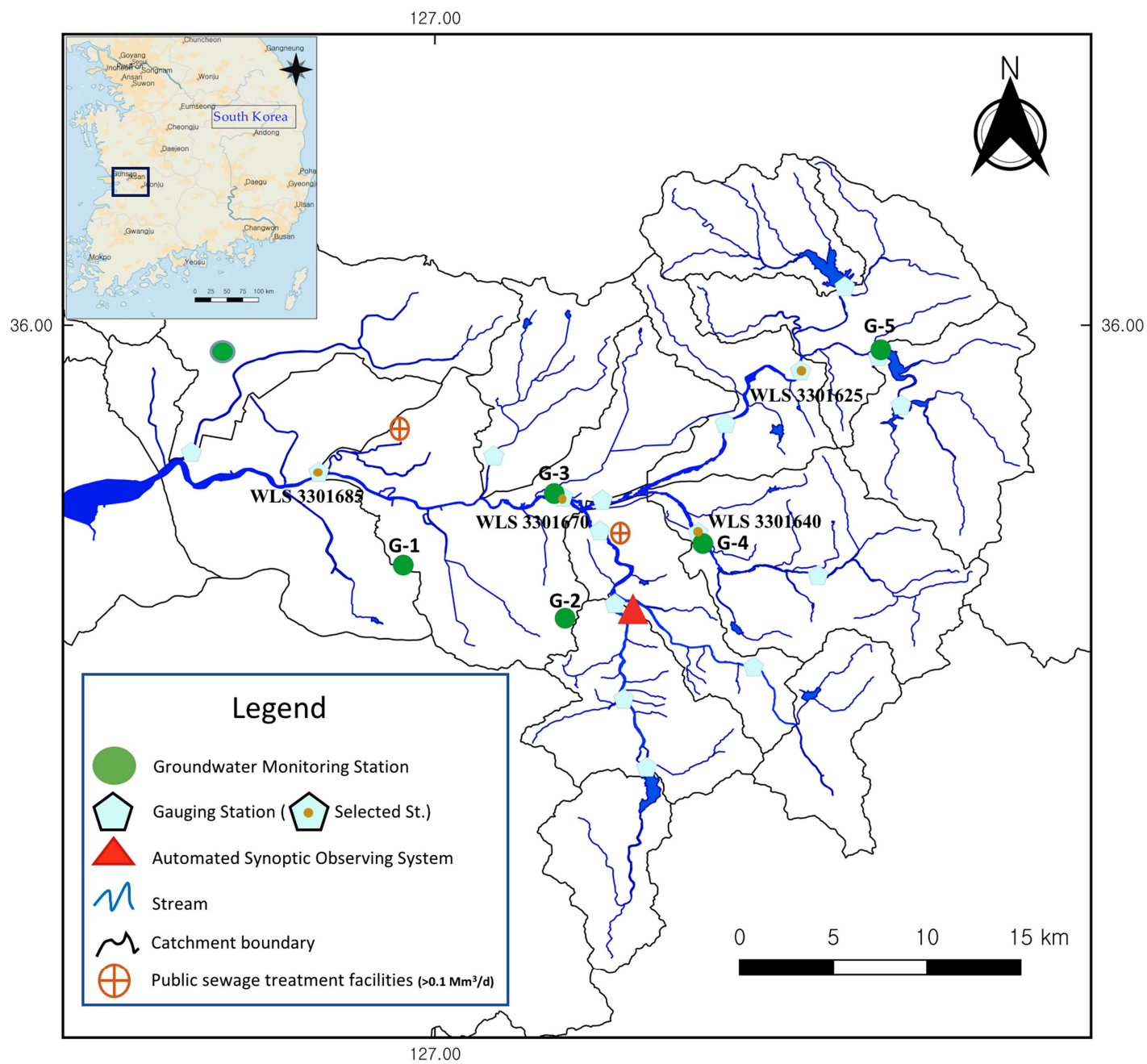

Figure 1. Catchment boundary and locations of each monitoring station in the Mangyeong River Basin, Korea (GIS source from WAMIS, http:/ / www.wamis.go.kr).

\section{Methods}

\subsection{Drought Propagation and the Relationship between Precipitation and Water Levels}

Meteorological drought caused by a lack of precipitation ultimately affects all elements of the hydrological cycle, resulting in a reduction of available water resources [38]. Hydrological droughts include both surface water (e.g., streams, lakes, reservoirs) and groundwater droughts [39]. The continuous lack of precipitation is propagated to the hydrological system, which affects surface runoff and soil moisture and the reduced recharge also affects groundwater storage and baseflow $[31,40,41]$. The propagation of drought has a different time scale for each hydrological factor [22].

Correlation analyses of each factor were conducted to calculate the relationship and lag-time of hydrological factors. Cross-correlation is commonly used to analyze the relationship between two time-series of data, $x$ and $y$. A cross-correlogram indicates the degree and direction of the relationship between random variables at different times [42,43]. The cross-correlation function is asymmetrical $\left(r_{x y}(k) \neq r_{y x}(k)\right)$. When $k>0$ (positive signal) and $r_{x y}(k)>0$, the input data affects the output data; when $k<0$ (negative signal) and $r_{y x}(k)>0$, the opposite effect occurs. Mayaud et al. [44] used the correlation analysis of discharge-discharge, rainfall-discharge, or water level-discharge in a karst area. When the correlation coefficient reaches a maximum, the lag of the cross-correlogram indicates 
a delay corresponding to the time taken for the variable $(x)$ to transfer to the other variable $(y)$. The cross-correlation function $\left(r_{x y}(k)\right)$ can be explained as in Larocque et al. [45]:

$$
\begin{gathered}
r_{x y}(k)=\frac{c_{x y}(k)}{\sigma_{x} \sigma_{y}} \\
c_{x y}(k)=\frac{1}{n} \sum_{t=1}^{n-k}\left(x_{t}-\bar{x}\right)\left(y_{t+k}-\bar{y}\right)
\end{gathered}
$$

where $c_{x y}(k)$ is the cross-covariance, $k$ is the time lag, $\bar{x}$ and $\bar{y}$ are the average values, $n$ is the total number of time series, $t$ is the measured time for the variable, $\sigma_{x}$ and $\sigma_{y}$ are the standard deviations of the two time-series data ( $x$ and $y$; input and output data), respectively.

To estimate the relationship and the lag among the rainfall, stream and groundwater, cross-correlation analysis was conducted.

\subsection{Standardized Precipitation Index for Estimating Meteorological Drought}

The Standardized Precipitation Index (SPI) is a key index for evaluating meteorological droughts using precipitation records as input data. It is based on a fitted model to a probability distribution of long-term cumulative precipitation data over the past 30 years, transforming it into a normal distribution, so that it can then estimate the severity of a drought [6]. Due to the high spatial and temporal variability of precipitation, the meteorological drought indices are often calculated using monthly values [46]. The estimation period can be calculated as the accumulated periods of 3, 6, 9, 12 and 24 months. This method has the advantage of evaluating the drought relatively easily and quickly because only the precipitation data are utilized [47]. The SPI has been recommended by the World Meteorological Organization (WMO) as a drought index for estimating meteorological droughts [48]; however, long-term SPI data are required and the degree of uncertainty is high because only precipitation is used as input data. In addition, it is difficult to link the SPI with the concept of an actual lack of available water resources, because it uses a deviation calculated from long-term data in the selected area. When evaluating the drought index, the characteristics of each region and factor should be considered. Approaches to estimate the drought severity index for hydrological droughts, such as the SGI [21] and the SDI [35,36], are also based on the SPI method.

In this study, the SPI-based drought severity index was estimated. However, it was impossible to apply the method under ideal conditions due to the discontinuity of data and the lack of data for the required period of at least 30 years. Therefore, this study used a 10-year data set for the Mangyeong River Basin and compared the results with other groundwater drought indicators.

\subsection{Groundwater Drought Analysis}

\subsubsection{Threshold Level Method}

Under natural conditions, groundwater drought is caused by a lack of precipitation followed by a decrease in recharge, resulting in decreases in GWL and discharge and eventually a decline in the available groundwater [49]. The "lack of precipitation" is usually determined by a comparison with a "normal" condition or a mean value from past measurements [49]. As noted by Mishra and Singh [31], the reason for analyzing the change in GWL rather than groundwater storage is that "defining or estimating the total available water is difficult and in most groundwater systems, negative impacts of storage depletion can be felt, long before the total volume of groundwater in storage is decreased" $[49,50]$. Therefore, most groundwater droughts are defined as water-level declines [28,29].

The threshold method was first developed by Yevjevich [51] in order to calculate hydrological drought. The threshold value is calculated from groundwater time-series data. From this, the groundwater drought duration, severity and frequency can be evaluated with respect to the reference value of the GWL (Figure 2, [52-54]). 


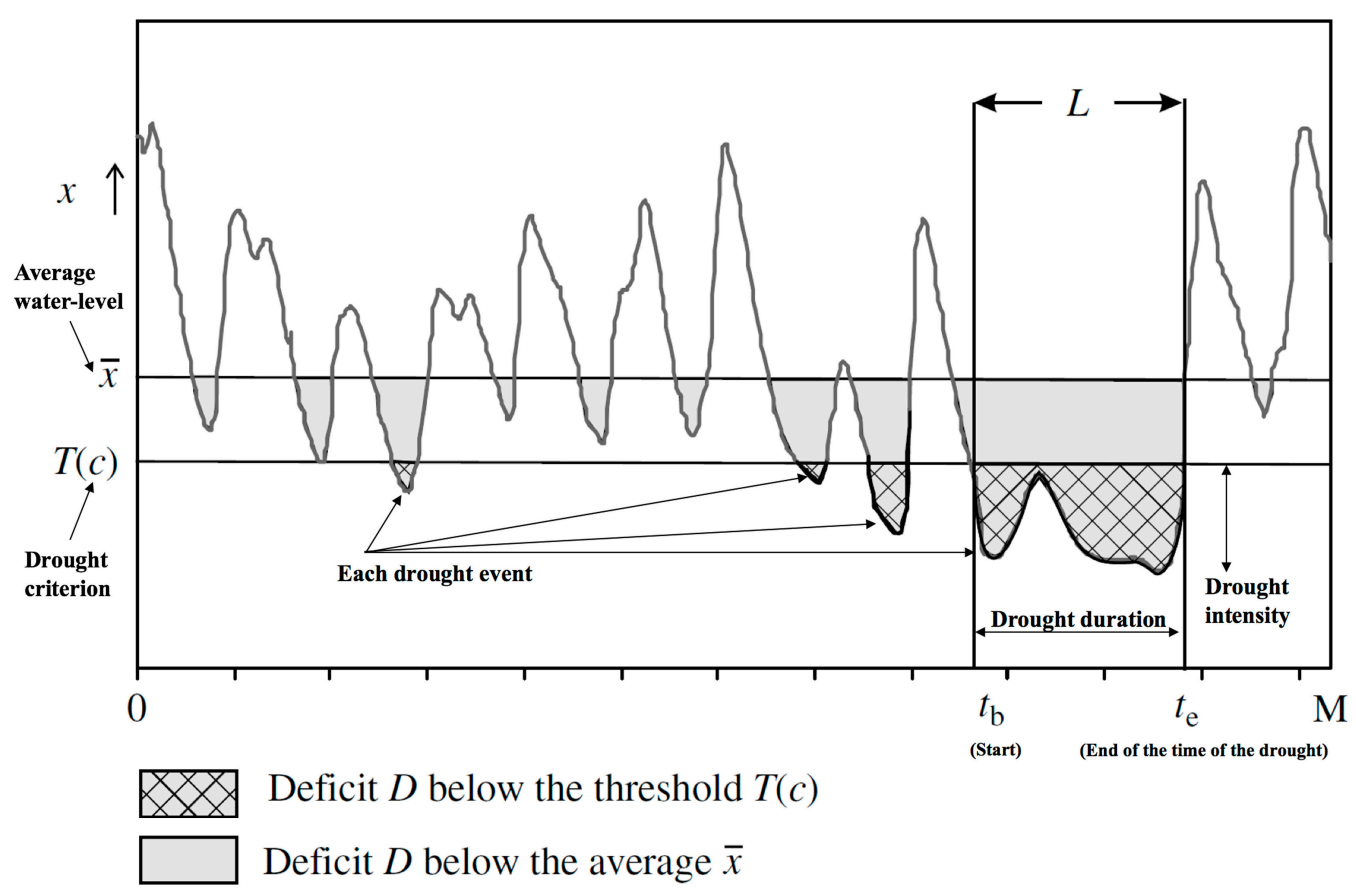

Figure 2. Illustration of the threshold level approach and the definition of the threshold level $T(c)$ for a time-series of water-level $(x)$ with average of length $(M)$ containing four droughts (modified from [53]).

According to Peters et al. [53], for any hydrologically relevant variable $x$ (e.g., water levels in this study), the deficit (D) below the threshold level ( $T$ ) which is the critical value for determining droughts from time series data and each drought event is estimated as:

$$
\mathrm{D}=\int_{t_{b}}^{t_{e}}(T-x(t)) d t
$$

where $t_{b}$ and $t_{e}$ are the start and end times of the drought, respectively. The threshold level $(T)$ is derived by relating the total deficit below the mean value to the total deficit below the threshold.

The duration (from $t_{b}$ to $t_{e}$ ) L is calculated as:

$$
\mathrm{L}=t_{e}-t_{b}
$$

The threshold function described in Figure 2 is given by:

$$
\int_{0}^{M}(T(c)-x(t))_{+} d t=c \int_{0}^{M}(\bar{x}-x(t))_{+} d t
$$

where,

$$
\begin{aligned}
& x_{+}=x, \text { if } x \geq 0 \\
& x_{+}=0, \text { if } x<0
\end{aligned}
$$

$M$ is the length of the time series and $T(c)$ is the threshold level determined by $c$ value which is the drought criterion. The $c$ value is the ratio of the deficit below the threshold to the deficit below the mean value over a particular period of time. At the threshold function, $c$ is a very important parameter regarding the estimation of groundwater drought conditions. The range of $c$ is from 0 to 1 . If $c=0$, the threshold is equal to the minimum value of the variable $x$. If $c=1$ the threshold is equal to the average value. Peters et al. [53] used a $c$ value that differed between 0.1 and 0.3 in their analysis and found the difference to be important, as it could affect the results of the drought evaluation. 


\subsubsection{The $95 \%$ Occurrence Method}

There are many groundwater drought estimation methods applicable at the watershed and various temporal scales. The probability of occurrence method is an easy and universal method that uses observed water-level fluctuations and has been applied in some areas [55]. According to Van Lanen and Peters [49], the 95\% probability of occurrence lines derived from the statistical analysis of past observations can be compared with the currently measured GWLs to determine the anomalies for each year or at specific time points.

\section{Data Acquisition}

\subsection{Groundwater Data}

The available groundwater monitoring data for the 11-year period from 2005 to 2015 were analyzed to calculate the change in the GWL. For the analysis, five groundwater monitoring stations were selected (Figure 1). The locations and the hydrogeological properties of the groundwater monitoring stations are described in Tables 1 and 2 and Figure 3. The well screen and perforated intervals of G-1 to G-5 are as follows: (G-1) 32-36, 40-44 and 48-52 m; (G-2) 7-11 m; (G-3) 11-15 m; (G-4) 8-12 m; and (G-5) 50-54, 58-62 and 66-70 m.

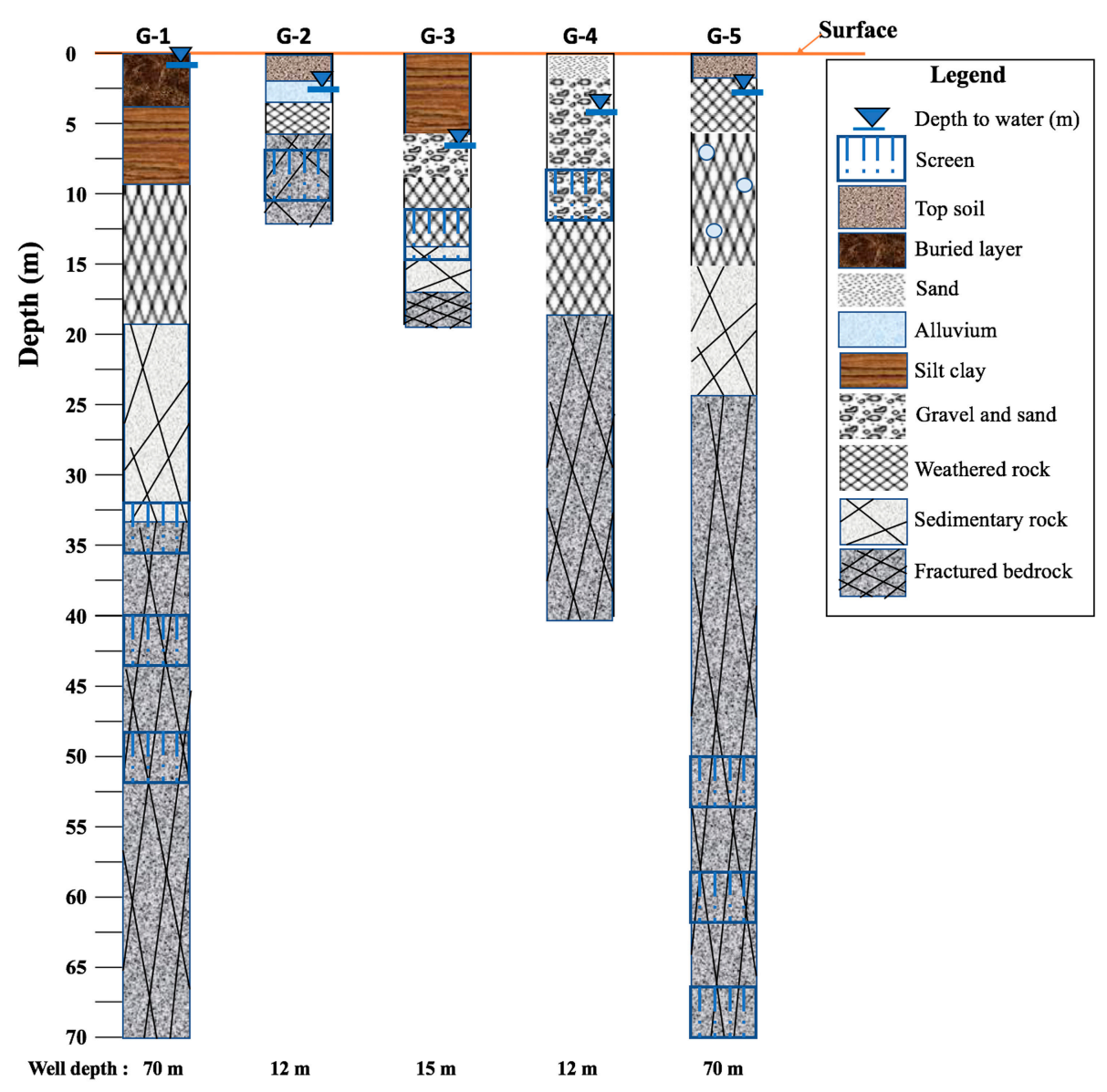

Figure 3. Lithologic profiles and well descriptions for the aquifers in the study area. 
Table 1. Summary information for the five groundwater monitoring stations, four gauging stations and weather station.

\begin{tabular}{|c|c|c|c|c|c|c|}
\hline Station & Name & Lat. & Lng. & $\begin{array}{c}\text { Distance from the } \\
\text { Weather Station }(\mathrm{km})\end{array}$ & $\begin{array}{l}\text { Elevation } \\
(\mathrm{m}, \text { amsl) }\end{array}$ & Remark \\
\hline ASOS-146 & Jeonju & 35.833333 & 127.116667 & 0 & 61.40 & Precipitation \\
\hline G-1 & GimjaeYongji & 35.858976 & 126.981332 & 12.5 & 15.04 & Groundwater \\
\hline G-2 & JeonjuManseong & 35.827778 & 127.076667 & 3.7 & 36.31 & Groundwater \\
\hline G-3 & WanjuSamrye & 35.901069 & 127.070253 & 8.6 & 15.57 & Groundwater \\
\hline G-4 & WanjuYongjin & 35.871667 & 127.157778 & 5.6 & 28.83 & Groundwater \\
\hline G-5 & WanjuGosan & 35.985575 & 127.262606 & 21.4 & 73.62 & Groundwater \\
\hline WLS $3301685^{*}$ & Mokcheon & 35.913336 & 126.931689 & 18.9 & -2.11 & Stream \\
\hline WLS 3301670 * & Daecheon & 35.898740 & 127.075324 & 8.2 & 2.93 & Stream \\
\hline WLS 3301640 * & Soyang & 35.877825 & 127.154989 & 6.0 & 21.25 & Stream \\
\hline WLS 3301625 * & Gosan & 35.973044 & 127.215364 & 17.9 & 43.25 & Stream \\
\hline
\end{tabular}

* Water-level (river stage) and discharge monitoring station.

Table 2. Details of the five groundwater monitoring stations in the Mangyeong River Basin (source: K-Water, http:/ / www.gims.go.kr).

\begin{tabular}{|c|c|c|c|c|c|c|c|c|}
\hline \multirow{2}{*}{ Station } & \multirow{2}{*}{ Aquifer } & \multirow{2}{*}{$\begin{array}{l}\text { Well Depth } \\
\text { (m) }\end{array}$} & \multicolumn{3}{|c|}{ Water-Level (EL, m) } & \multirow{2}{*}{$\begin{array}{l}\text { Mean Depth } \\
\text { to Water (m) }\end{array}$} & \multirow{2}{*}{$\begin{array}{c}\text { Hydraulic } \\
\text { Conductivity } \\
\text { (m/Day) }\end{array}$} & \multirow{2}{*}{$\begin{array}{l}\text { Storage } \\
\text { Coefficient }\end{array}$} \\
\hline & & & Max. & Min. & Mean & & & \\
\hline G-1 & Biotite granite (Bedrock) & 70 & 14.24 & 11.58 & 13.67 & 0.55 & 0.34 & 0.0556 \\
\hline G-2 & Gneissic granite (Alluvial) & 12 & 32.07 & 27.65 & 29.95 & 2.75 & 0.01 & - \\
\hline G-3 & $\begin{array}{l}\text { Schistose granite } \\
\text { (Alluvial) }\end{array}$ & 15 & 10.88 & 8.16 & 9.45 & 6.60 & 0.23 & 0.0342 \\
\hline G-4 & Biotite granite (Alluvial) & 12 & 25.21 & 23.02 & 23.79 & 3.77 & 0.01 & - \\
\hline G-5 & Volcanic rocks (Bedrock) & 70 & 69.74 & 67.27 & 68.55 & 2.62 & 0.25 & - \\
\hline
\end{tabular}

\subsection{Precipitation Data}

Precipitation data were collected from the automated synoptic observing system (ASOS) operated by the Korea Meteorological Administration (KMA: Figure 1; Table 1). Accumulated daily and monthly precipitation data and the coordinates of the ASOS (Jeonju station) in the Mangyeong River Basin were used to calculate the distance between the ASOS and the groundwater monitoring wells and to analyze the corresponding water-level fluctuations (http:/ / data.kma.go.kr/). Precipitation data was available for the period of 2005-2015. However, to estimate the monthly SPI index, the period of 1986-2015 was analyzed.

\subsection{Stream Data (Gauging Station)}

Gauging stations have been installed for floods forecasting and warning during the rainy season; the river stage or discharge in the watershed is measured every hour. In this study, four stations located in upstream and downstream areas were selected and analyzed for linkages with groundwater stations (Figure 1; Table 1). Both river stage and discharge were monitored at each gauging station using an automatic sensor. However, due to the data quality and recording period, only the streamflow data from WLS 3301670 and WLS 3301625 were analyzed. For these stations, real-time and processed data were available online (Water Management Information System; http://www.wamis.go.kr/, River Flood Control Office; http:/ / www.hrfco.go.kr/, www.yeongsanriver.go.kr/). The average daily and monthly water levels observed from the gauging stations in the Mangyeong River Basin were used for analysis.

\section{Results and Discussion}

\subsection{Propagation of the Precipitation, Surface Water and Groundwater}

As noted by Van Lanen and Peters [49], a groundwater drought only develops if a reduced recharge coincides with low groundwater storage due to antecedent meteorological conditions. 
An analysis of the rainfall characteristics of the Mangyeong River Basin was performed first, then the correlation between rainfall and groundwater was determined. Also, groundwater recharge was calculated using the modified water-table fluctuation (WTF) method (Figure S1; Table S1) and compared with air temperature and evaporation (Figure S2). The average annual precipitation in the Mangyeong River Basin measured at the Jeonju weather station over a 30-year period (1986-2015) was about $1298.7 \mathrm{~mm}$ and the average annual precipitation from 2005 to 2015 (the period for which groundwater monitoring data was available) was $31.3 \mathrm{~mm}$ less than normal. The recorded precipitation reached a low of about $1000 \mathrm{~mm}$ in 2008 but was more than $1600 \mathrm{~mm}$ in 2011 (Table S2). However, since 2012, it has decreased again. In 2015, the annual precipitation was only $813.5 \mathrm{~mm}$, which is about $63 \%$ of the average (Figure 4; Table S2).

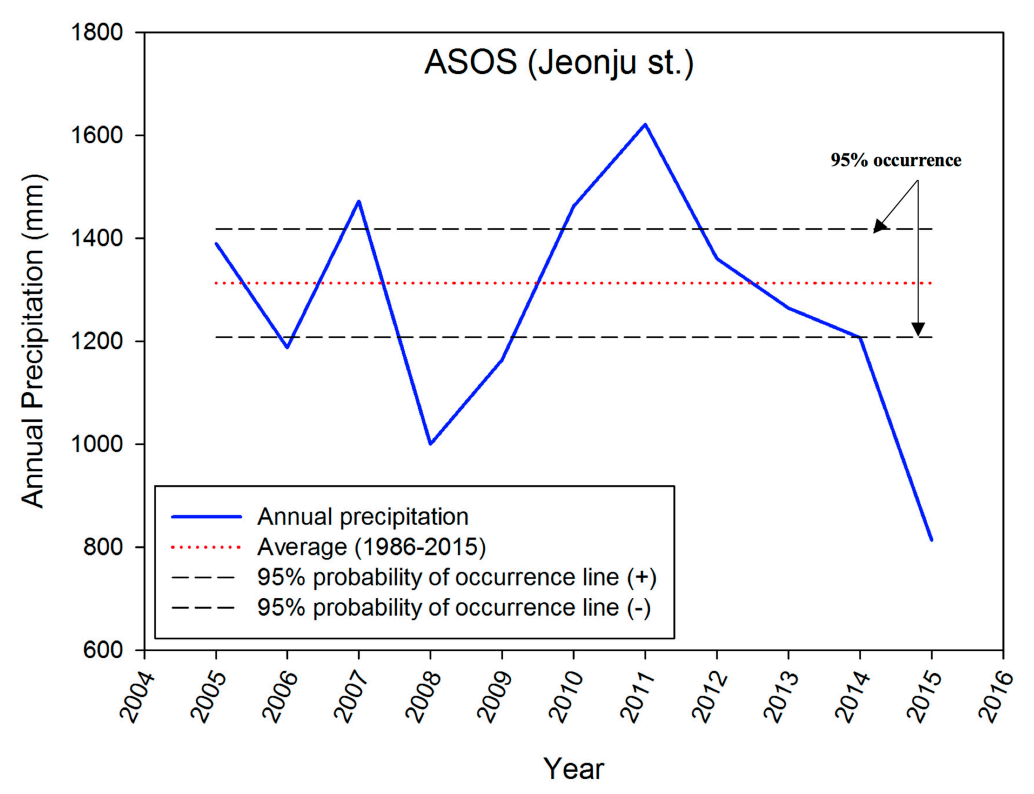

Figure 4. Changes in annual precipitation at the Jeonju automated synoptic observing system (ASOS) station in the Mangyeong River Basin.

The GWL changes did not necessarily coincide with the precipitation trend. Therefore, a cross-correlation analysis was conducted to estimate the correlation and time lag among the precipitation, surface water and groundwater. In general, the anomalies caused by the deficit of precipitation were propagated as follows: precipitation $\rightarrow$ runoff $\rightarrow$ soil moisture $\rightarrow$ surface water (e.g., streams, rivers, lakes) $\rightarrow$ groundwater fluctuation [22].

In the analysis of the variation of each hydrologic factor, water levels but not the flow rate, were compared to the rainfall and GWLs. It is difficult to compare the anomalies because the discharge approached zero in spring every year and the flow rate and the river stage were strongly correlated with each other as shown in Figure 5. 


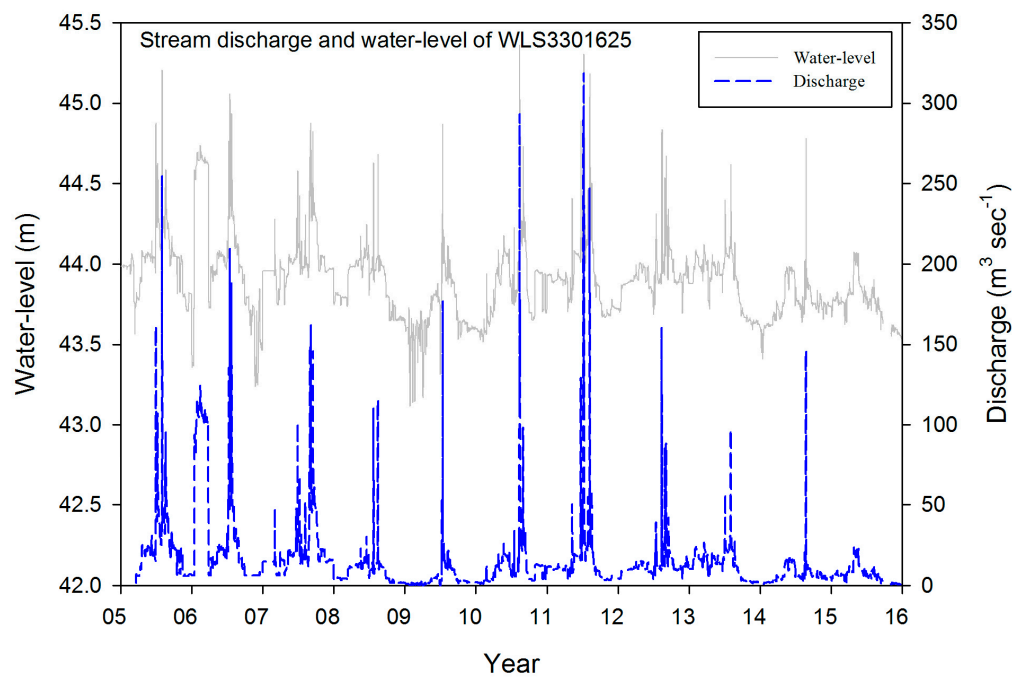

Figure 5. Comparison of a time series of stream discharge (blue dotted line) and river stage (grey solid line) at a gauging station in the Mangyeong River Basin.

Figure 6 shows changes in the precipitation measured at the weather station, the water levels at four stream gauging stations (WLS 3301625, WLS 3301640, WLS 3301670 and WLS 3301685) and the water-level fluctuations at the five groundwater monitoring stations (two bedrock aquifers: G-1 and G-5; three alluvial aquifers: G-2, G-3 and G-4). Because Korea is located in the East Asian Monsoon region, precipitation shows both annual and seasonal cycles with about $67.8 \%$ of the total annual precipitation concentrated in the short wet season (June-September). In 2008 and 2015, when the amount of precipitation was 267 and $454 \mathrm{~mm}$ lower than the normal level (1267 mm) of rainfall, respectively, the amount of rainfall in the wet season was relatively low (about 192 and $543 \mathrm{~mm}$ lower, respectively). The river stage measured at the downstream station (WLS 3301685) was correlated with the precipitation and was relatively low as 0.337 due to the decrease in discharge in 2008 and 2015 when the precipitation was low (Table 3; Figure 6a). However, the water-level at the nearby groundwater monitoring station G-1 decreased in the spring (March-May) and autumn (October-November) and increased in summer (June-September). The correlation coefficient for the relationship with precipitation was low as 0.085 (Table 3; Figure 6a). This was attributed to groundwater abstraction for agricultural use from nearby wells.

Table 3. Relationship among rainfall, surface water and groundwater.

\begin{tabular}{|c|c|c|c|c|c|c|c|c|c|c|}
\hline Station & Rainfall & $\begin{array}{c}\text { WLS } \\
3301685 \\
\end{array}$ & $\begin{array}{c}\text { WLS } \\
3301670\end{array}$ & $\begin{array}{c}\text { WLS } \\
3301640\end{array}$ & $\begin{array}{c}\text { WLS } \\
3301625 \\
\end{array}$ & G-1 & G-2 & G-3 & G-4 & G-5 \\
\hline Rainfall & 1.000 & & & & & & & & & \\
\hline $\begin{array}{c}\text { WLS } \\
3301685\end{array}$ & 0.337 * & 1.000 & & & & & & & & \\
\hline $\begin{array}{c}\text { WLS } \\
3301670\end{array}$ & $0.746^{* *}$ & $0.396^{* *}$ & 1.000 & & & & & & & \\
\hline $\begin{array}{c}\text { WLS } \\
3301640\end{array}$ & $0.600 * *$ & $0.355^{* *}$ & $0.555^{* *}$ & 1.000 & & & & & & \\
\hline $\begin{array}{c}\text { WLS } \\
3301625\end{array}$ & $0.502 * *$ & 0.512 ** & $0.728^{* *}$ & $0.587^{* *}$ & 1.000 & & & & & \\
\hline G-1 & 0.085 & 0.092 & $0.182 *$ & 0.075 & 0.136 & 1.000 & & & & \\
\hline G-2 & -0.035 & $-0.560^{* *}$ & 0.038 & -0.042 & -0.004 & 0.180 * & 1.000 & & & \\
\hline G-3 & $0.454^{* *}$ & 0.079 & $0.443^{* *}$ & $0.483^{* *}$ & 0.399 ** & 0.006 & 0.392 ** & 1.000 & & \\
\hline G-4 & $0.749^{* *}$ & 0.450 ** & $0.744^{* *}$ & $0.759 * *$ & $0.583^{* *}$ & 0.194 * & 0.012 & $0.508^{* *}$ & 1.000 & \\
\hline G-5 & $0.600 * *$ & $0.566^{* *}$ & $0.540^{* *}$ & $0.576^{* *}$ & $0.519 * *$ & 0.094 & $-0.250^{* *}$ & $0.248^{* *}$ & $0.604^{* *}$ & 1.000 \\
\hline
\end{tabular}



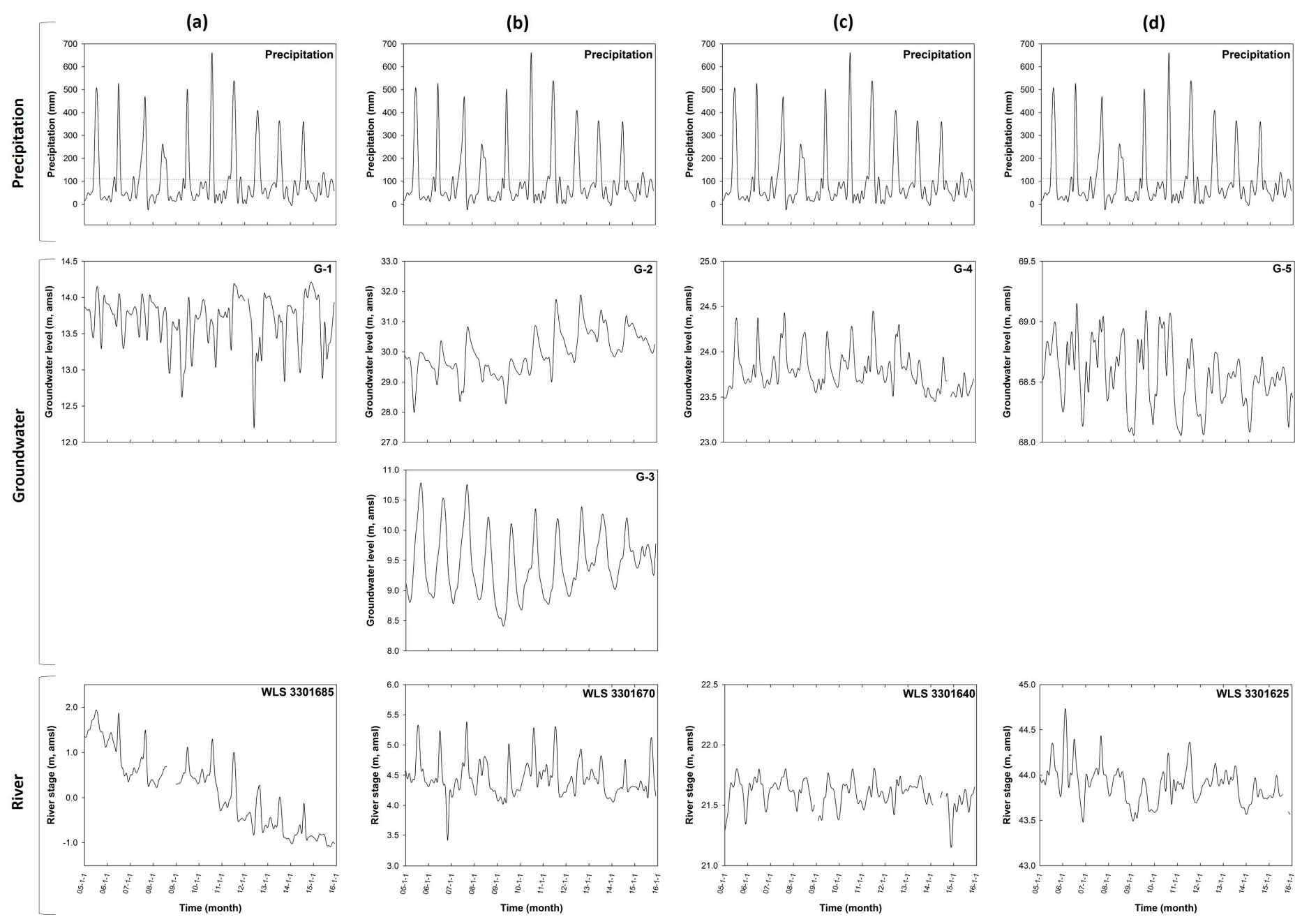

Figure 6. Monthly time series of variations in precipitation, stream (river stage) and groundwater level in the Mangyeong River Basin from January 2005 to December 2015 (a) Precipitation, WLS 3301685: stream water-level, G-1: groundwater level; (b) Precipitation, WLS 3301670: stream water-level, G-2 and G-3: groundwater levels; (c) Precipitation, WLS 3301640: stream water-level, G-4: groundwater level; and (d) Precipitation, WLS 3301625: stream water-level, G-5: groundwater level. 
The river stage in WLS 3301670 was generally well correlated with precipitation (low water-level in 2008) but on one occasion in 2006 an anomalous level was apparent and the river stage in 2015 (i.e., a drought year) did not match the precipitation. The GWLs of the nearby gauging stations, G-2 and G-3 also displayed seasonally fluctuating characteristics, with a low peak in the drought periods of 2008 and 2015, although the overall tendency was for an increase in G-2 (Figure 6b). However, the WLS3301685 and WLS3301670 gauging stations recorded sewage discharges of 100,000 and $403,000 \mathrm{~m}^{3} / \mathrm{d}$ from the adjacent public sewage facilities, respectively (Figure 1 ). This may have affected the correlation among precipitation, stream and groundwater using the data observed at the two points.

At WLS 3301640, there was a relatively low river stage variation of $0.5 \mathrm{~m}$; however, the river stage was lower during drought periods. The lowest GWL fluctuation was observed at G-4, where there was an overall declining trend in 2015 when extreme drought occurred (Figure 6c). The water levels of the WLS 3301625 and G-5 wells, which were located at high altitude in the upstream area, displayed a decreasing trend (Figure 6d). Figure 5 shows that during precipitation events, the stream discharge increased rapidly due to precipitation and direct runoff and there was an almost simultaneous fluctuation with the water-level of the river. As in a general hydrograph, after the stream flow increased, the GWL also rose. The decrease in water-level during the drought season was affected by spring precipitation but was more significantly influenced by precipitation in the rainy season of the previous year (Figure 7). The monthly average GWLs of G-4 and G-5 were 23.56 and $68.07 \mathrm{~m}$ in January 2009 and the lowest river stages of WLS3301640 and WLS3301625 in 2008-2009 were 21.37 and $43.50 \mathrm{~m}$, respectively. The effects of the precipitation anomaly transferred to the soil moisture content, runoff, stream discharge and groundwater depletion processes. Although the precipitation was less than the mean value in the Mangyeong River Basin during the drought period, the droughts did not lead to serious or prolonged water deficits. In addition, due to the seasonal rainfall cycle, the shortage of rainfall in spring was the main cause of the decrease in water storage in the following year.

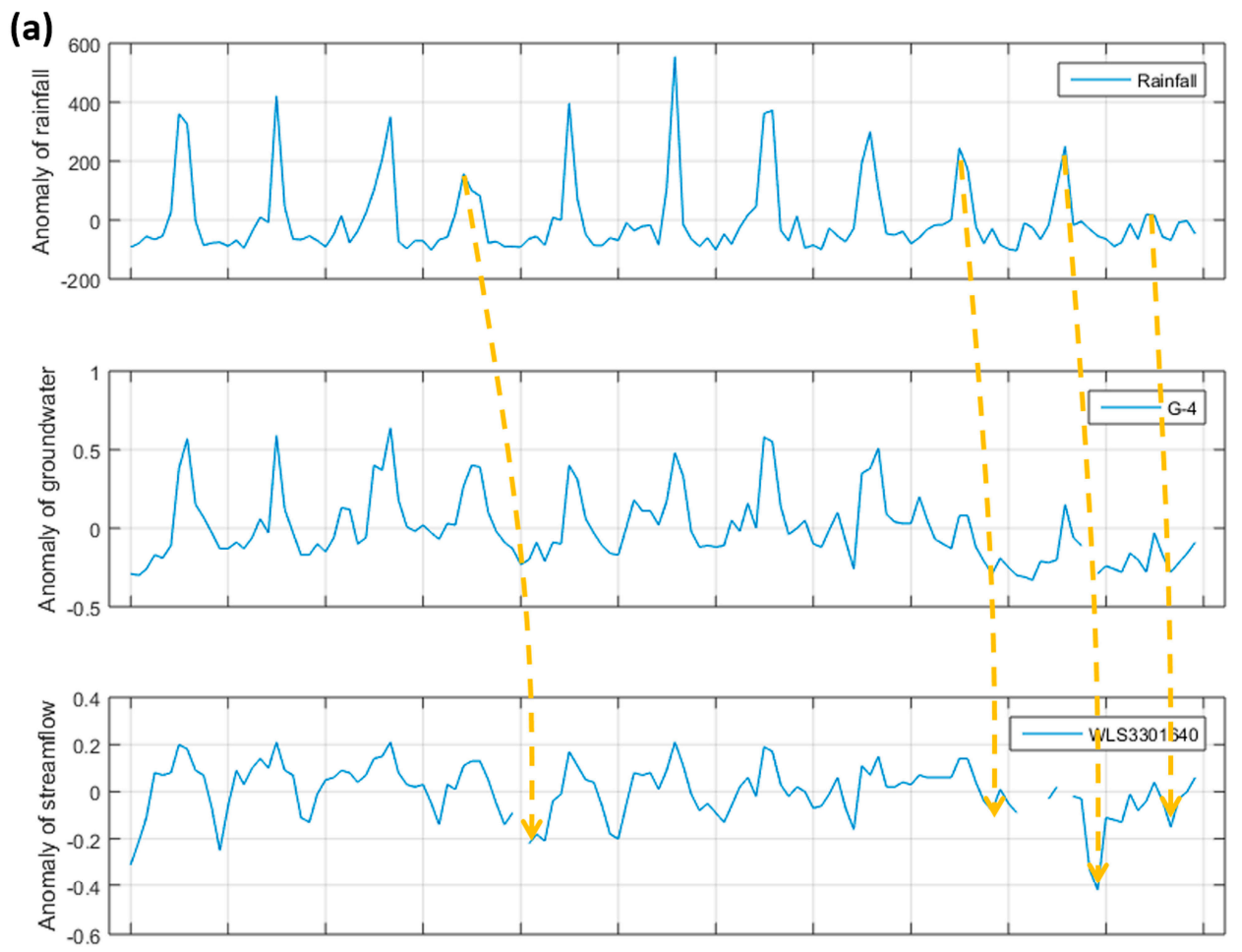

Figure 7. Cont. 
(b)

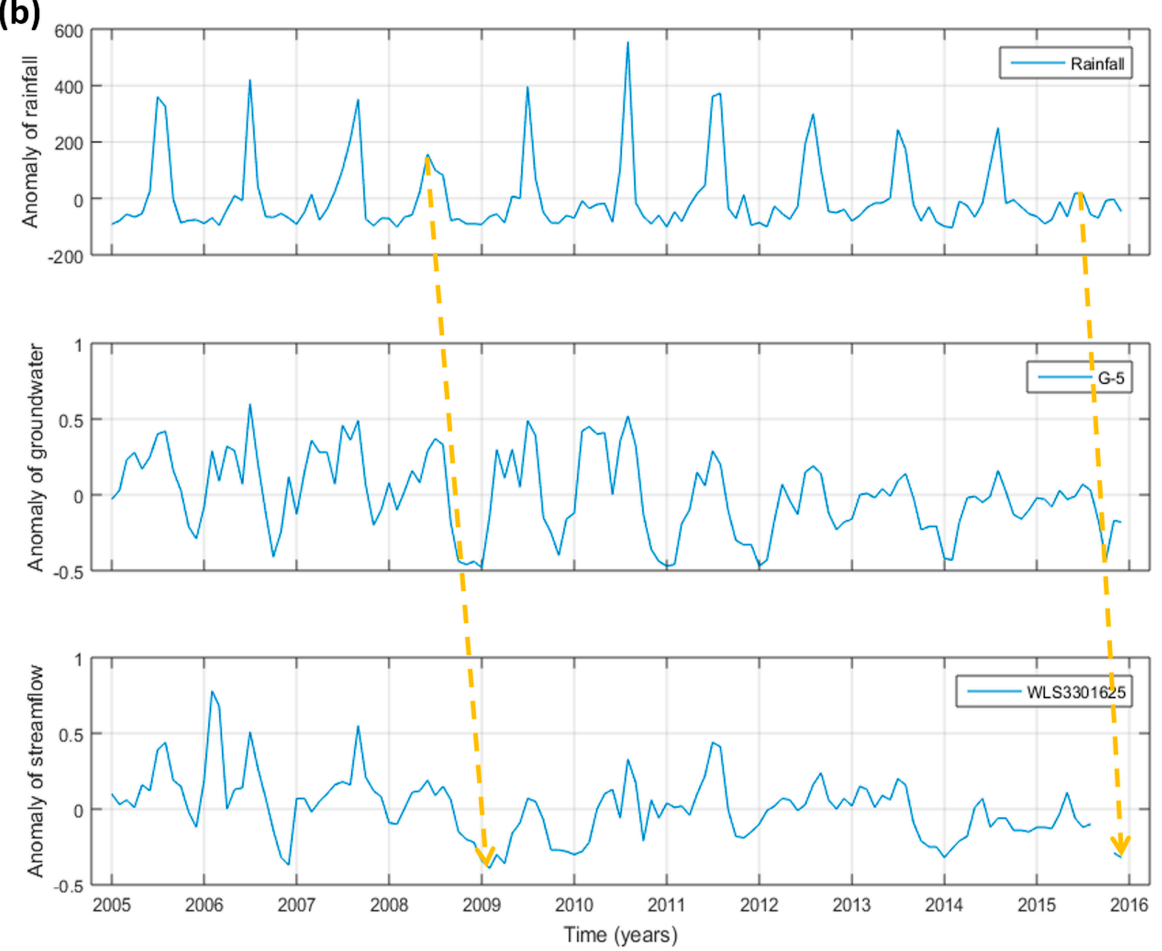

Figure 7. Time series anomalies of the precipitation, groundwater and streamflow with the propagation paths of (a) G-4 and WLS3301640; and (b) G-5 and WLS3301625 (Anomaly means a deviation from the mean value of each time series and the yellow lines are assumed to be the propagation of drought events).

In G-4 (alluvial aquifer) and G-5 (bedrock aquifer), located in the upstream area of the watershed, the water-level tended to decrease with decreasing precipitation. On the other hand, we considered that the impact of recharge would be low at the G-2 (alluvial) with an altitude of $36.31 \mathrm{~m}$ and a depth to water of $2.75 \mathrm{~m}$, because the correlation coefficient for the relationship with rainfall was less than 0.1 ; however, the water-level displayed an increasing trend (Tables 2 and 3 ).

G-1 (bedrock) and G-3 (alluvial), which were located at a relatively low altitude of about $15 \mathrm{~m}$, displayed different GWL fluctuations (Table 1). Although the average thickness of the unsaturated zone of G-1 was thin at only $0.55 \mathrm{~m}$, the correlation coefficient for its relationship with precipitation was as low as 0.1. In the spring and autumn, the GWL dropped rapidly and a recovery pattern then appeared during the summer seasons. This was probably due to the influence of artificial water use (e.g., groundwater abstraction). The mean depth to water at G-3 was $6.60 \mathrm{~m}$ but the correlation coefficient for the relationship with precipitation was 0.454 (Tables 2 and 3) and the peak GWL was low when the precipitation was low. However, it is difficult to use this relationship to estimate drought severity, because the GWL did not reach the lowest point during 2015 when the lowest precipitation was recorded.

As shown in Table 3, the correlation coefficients between precipitation and the water-level at WLS 3301685 (0.337) and groundwater (G-1: 0.085, G-2: -0.035) were low. The low correlation between precipitation and the river stage (WLS3301685) was attributed to the floodgate being located in the downstream area and tidal effects creating a noise signal within the water-level changes. In addition, the weak correlation between precipitation and GWL (G-1 and G-2) could have been caused by the effect of water abstraction due to agricultural activities in the region [56]. The water levels measured at each point along the river (upstream to downstream) were well correlated (correlation coefficient: 0.454-0.749). The correlation coefficients for the relationships between the hydrological elements, except for WLS 3301685, G-1 and G-2, were in the range of 0.399-0.749. 
A cross-correlation analysis was conducted to estimate the direction and lag time of the propagation between precipitation, surface water and groundwater (Table 4). A correlation analysis using daily data is difficult because precipitation has a large temporal deviation. For this reason, we used monthly data for the cross-correlation analysis. The time lag between the monthly mean GWL of G-3 and the monthly cumulative precipitation was calculated to be one month. The GWLs of the other stations had zero time lag (maybe less than one month). Because the monitoring well of G-3, adjacent to the river has a silt and clay on top layer and the depth to water is deep as $6.60 \mathrm{~m}$. The lag time calculated in this study was similar to the values obtained by Bloomfield and Marchant [21], where were mostly zero months. This can be explained by the fact that the rainfall anomaly propagates to the groundwater within one month due to the rapid drainage or high permeability of the hydrogeology. On the other hand, when monthly data are used, short-term drought events (weeks or days) may not be detected by the groundwater drought method.

Table 4. Summary of the aquifer type, threshold value, correlation coefficient for the relationship with rainfall, lag-time and the results of the duration and frequency estimated by the threshold method for groundwater drought in each monitoring well.

\begin{tabular}{|c|c|c|c|c|c|c|c|c|c|c|}
\hline \multirow{2}{*}{ Station } & \multirow{2}{*}{$\begin{array}{l}\text { Aquifer } \\
\text { Type }^{a}\end{array}$} & \multirow{2}{*}{$\begin{array}{l}\text { Elevation } \\
\text { (m) }\end{array}$} & \multicolumn{2}{|c|}{$\begin{array}{l}\text { Threshold } \\
\text { (m) }\end{array}$} & \multirow{2}{*}{$\begin{array}{c}\text { Cross } \\
\text { Correlation }\end{array}$} & \multirow{2}{*}{$\begin{array}{l}\text { Lag-Time } \\
\text { (Month) }\end{array}$} & \multicolumn{2}{|c|}{ Drought ( $c 0.3$ ) } & \multicolumn{2}{|c|}{ Drought ( $c$ 0.1) } \\
\hline & & & $c 0.3$ & c 0.1 & & & Duration (L) ${ }^{c}$ & Frequency & Duration $(\mathrm{L})^{\mathrm{c}}$ & Frequency \\
\hline G-1 & SC & 15.04 & 13.19 & 12.85 & 0.26 & 0 & 23 & 22 & 19 & 14 \\
\hline G-3 & ND & 15.57 & 9.08 & 8.87 & 0.72 & 1 & 125 & 9 & 81 & 7 \\
\hline G-4 & SC & 28.79 & 23.65 & 23.56 & 0.75 & 0 & 75 & 16 & 51 & 12 \\
\hline G-5 & UC & 73.62 & 68.32 & 68.19 & 0.60 & 0 & 63 & 14 & 49 & 11 \\
\hline
\end{tabular}

a Aquifer type determined by Lee et al. [57] (UC: unconfined aquifer/SC: semi-confined aquifer/C: confined aquifer/ND: not determined); ${ }^{\mathrm{b}}$ Cross-Correlation: correlated with monthly precipitation; ${ }^{\mathrm{c}}$ Average duration for each drought event (unit: day).

\subsection{Estimated SPI and the Correlation between the SPI and Groundwater Drought}

Annual cumulative precipitation was compared for different time periods, while the meteorological drought indices for 3, 6 and 12 months were calculated using 30-year rainfall data from 1986 to 2015 and the SPI (Figure 8). SPI values of less than -1 (black dotted line) indicate a moderate-to-severe drought; an extreme drought is indicated for SPI values below -2 (red double dotted line) [6]. The SPI results for the 2005-2015 period, which can be compared with the water-level data, showed that weak droughts over SPI accumulation periods of 3 and 6 months have occurred every year and extreme drought events occurred in 2008-2010 and 2015 for SPI accumulation periods of 12 months. The WMO [48] reported that the 12-month scale is adequate for assessing long-term variability of surface water or groundwater. The SPI results for accumulation periods of 12 months in the Mangyeong River Basin were in good agreement with the drought assessment report (Table 5).

Table 5. Summary of the main drought events that have occurred in the areas around the Geum River Basin after 2000 (modified from K-Water).

\begin{tabular}{|c|c|c|c|}
\hline \multicolumn{2}{|c|}{ Drought Periods } & \multirow{2}{*}{$\frac{\text { Impact or Management }}{\text { Action }}$} & \multirow{2}{*}{$\begin{array}{c}\text { Drought Condition } \\
30 \% \text { of normal rainfall (August-October) } \\
67 \% \text { reservoir storage ( } 8 \% \text { higher than normal) }\end{array}$} \\
\hline 2006 & October & & \\
\hline $2008 \sim 2009$ & September February & Local damage & $\begin{array}{c}46.4 \% \text { of annual mean rainfall (southern area: } 34 \%) \\
58 \% \text { of mean reservoir storage ( } 25 \% \text { higher than normal) }\end{array}$ \\
\hline \multirow{3}{*}{2012} & \multirow{3}{*}{ May June } & Action & $32 \%$ of annual mean rainfall \\
\hline & & No damage & $\begin{array}{l}\text { Rainfall: Gyeonggi-do 15\%, Chungcheongnam-do 19\%, } \\
\text { Jeollabuk-do 21\%, Jeollanam-do } 23 \%\end{array}$ \\
\hline & & - & Reservoir storage: $40 \%$ ( $47 \%$ higher than normal) \\
\hline 2014 & July & $\begin{array}{l}\text { Restrictions on water supply for } \\
\text { domestic water }\end{array}$ & $\begin{array}{l}50-61 \% \text { of normal rainfall } \\
\text { (Seoul, Gyeonggi-do, Chungcheong-do) }\end{array}$ \\
\hline 2015 & August November & $\begin{array}{l}\text { Restrictions on water supply for } \\
\text { industrial and domestic water }\end{array}$ & $\begin{array}{c}\text { Eight metropolitan areas in Chungcheongnam-do and } \\
\text { most areas in Gyeonggi-do at a 'severe' level } \\
\text { Low reservoir storage level }\end{array}$ \\
\hline
\end{tabular}




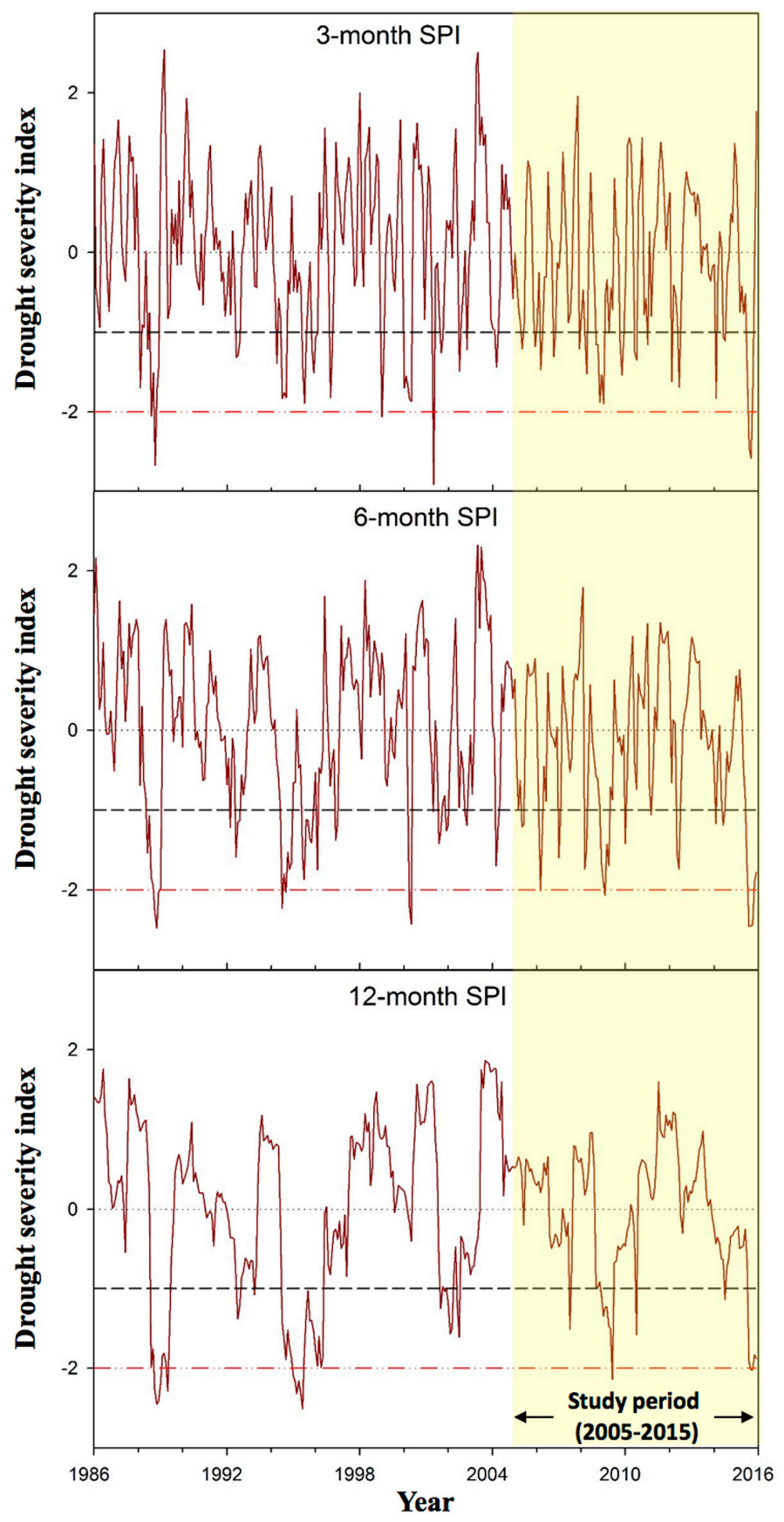

Figure 8. Drought severity index results using the standardized precipitation index (SPI) method for Jeonju station, Korea, 1986-2015.

\subsection{The Threshold and Occurrence of Groundwater Drought}

As shown in Figure 4, the annual precipitation began to decrease compared with the long-term average after 2011, with the amount of $814 \mathrm{~mm}$ in 2015 being the lowest value during the 2005-2015 period. The SPI index indicated a severe drought in 2015 (Figure 8). This corresponds to a precipitation deficit, according to the definition of meteorological drought but does not mean a deficit of available water. Therefore, we attempted to evaluate groundwater drought in the study area using the threshold method and the $95 \%$ occurrence method. 


\subsubsection{Threshold Level Method}

Based on the mean value and the threshold level of the time series data for the period of interest, a groundwater drought can be considered to occur when the water-level is below the reference value. In this study, the assessment of groundwater drought was conducted using GWL data from 2005 to 2015 at five stations in the Mangyeong River Basin (Figure 9).

(a)

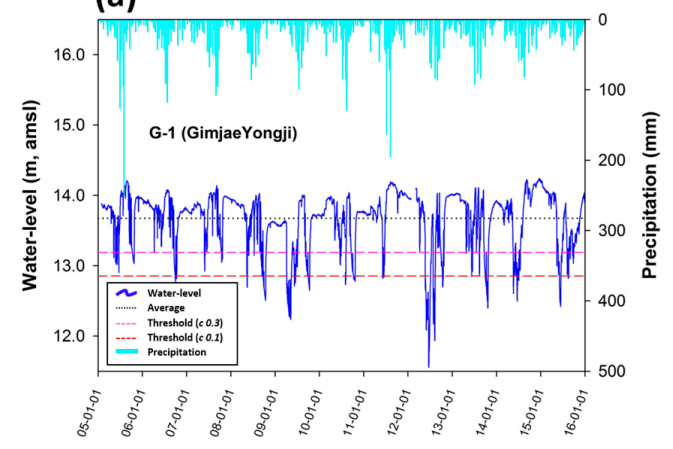

(c)

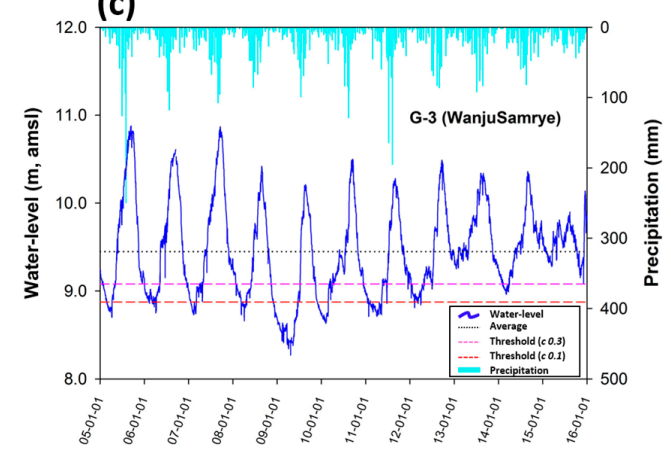

(b)

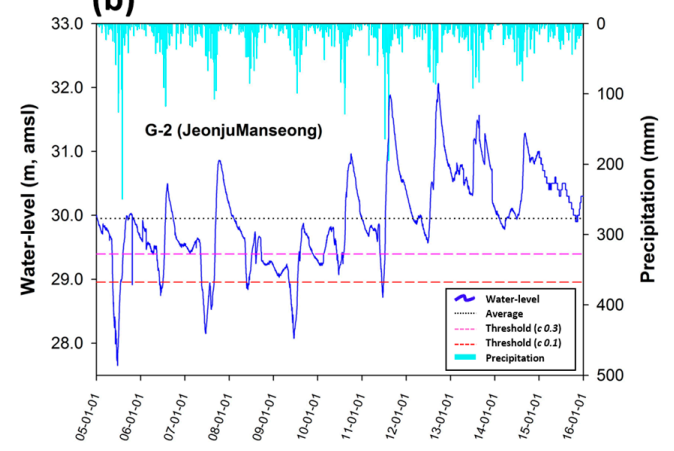

(d)

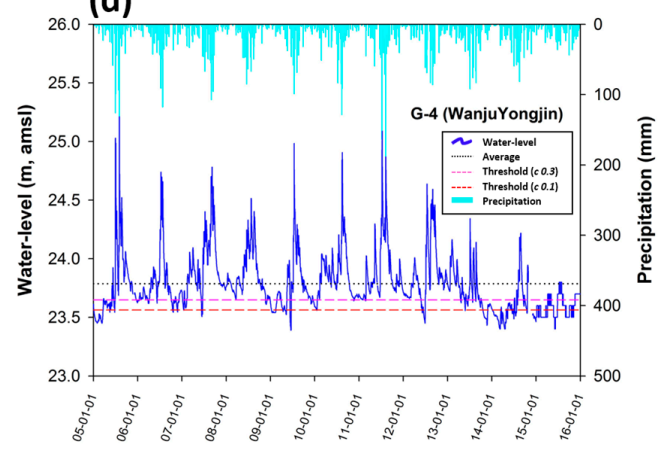

(e)

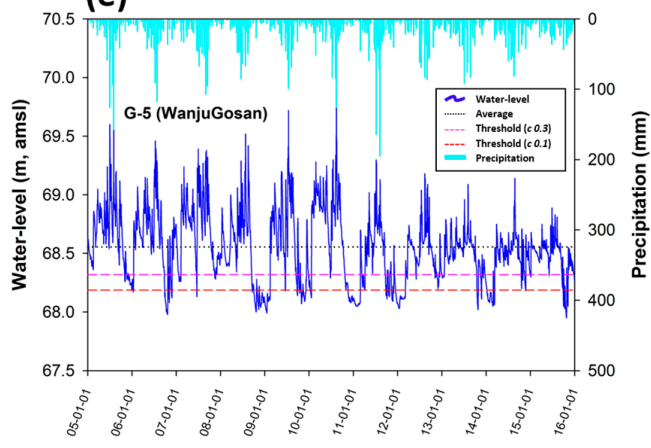

Figure 9. Threshold level (red dotted line) and average level (blue dotted line) for the time series variables of groundwater-level (blue line) and precipitation (light blue bar) during 2005-2015 at (a) G-1; GimjaeYongji; (b) G-2, JeonjuManseong; (c) G-3, WanjuSamrye; (d) G-4, WanjuYongjin; and (e) G-5, WanjuGosan.

In the threshold equation, when the $c$ value (threshold criterion) was applied as 0.3 , the results showed that seasonal groundwater droughts occurred almost every year at all monitoring wells (G-1 to G-5). There was a much lower GWL at G-1, which was assumed to be caused by water abstraction for agricultural use in spring and fall (Figure 9a) during the drought period (2009 and 2012), as determined by the drought report (Table 5). It is likely that the use of groundwater increased due to the decrease in both reservoir storage and surface water during the drought period. If anthropogenic factors influence the lack of water, drought can be aggravated with respect to the natural situation $[30,58]$. 
Seasonal groundwater droughts appeared at well G-2 every year until 2011 but since 2012 the overall GWL increased and the lowest GWL settled near the average GWL (Figure 9b). In G-3, seasonal groundwater droughts occurred repeatedly and GWLs declined most severely during the 2008-2009 drought. Since 2012, the range of the water-level fluctuation and the height of the GWL have decreased. A severe drought occurred in 2015 but the lowest GWL was above the threshold level (Figure 9c). There were seasonal groundwater droughts at G-4 and G-5 but the groundwater drought frequency and severity were not substantially below the thresholds and the droughts of 2008-2009 and 2015 were reflected in the data (Figure 9d,e). If the GWLs were below the threshold level during 2015 and there is insufficient amount of rainfall to recover during the next spring season, the severe groundwater drought also might be occurred toward 2016.

The drought severity (difference between the threshold value and minimum GWL), duration and frequency at which the GWL fell below the threshold value are shown in Table 5 . The frequency of drought was strongly correlated with the 3- and 6-month SPI values and the duration and severity of drought were strongly correlated with the 12-month SPI. In Korea, if the value of 0.3 is applied as the $c$ parameter in the threshold equation, the threshold value is set at a high level, with increasing drought frequency. However, if the value of 0.1 is applied as $c$ in the threshold equation, the threshold value may be too low to accurately detect the drought situation.

\subsubsection{The $95 \%$ Occurrence Method}

Groundwater drought was evaluated by calculating the $95 \%$ probability occurrence line for 11 years from 2005 to 2015. Such evaluations of water levels of groundwater monitoring can quickly detect when a time series reaches the critical level [49]. Groundwater droughts can be determined if the observed GWL is below the $95 \%$ occurrence line. In G-1, groundwater droughts occurred in early 2009, 2012 and from 2013 to 2015 (Figure 10a). The hydrograph for G-2 showed that a water deficit continued because the GWL was below the 95\% occurrence line in 2005, 2007 and June 2008 to April 2010. However, because the GWL was above the $95 \%$ occurrence level after 2012, it is likely that water resources were abundant during the period (Figure 10b). In G-3, the groundwater time series was located below the 95\% occurrence line from September 2008 to June 2009 and this was determined to be a drought period. It recovered temporarily during the wet season but the water-level declined again from September to December 2009. The hydrograph of G-3 was similar to that of G-2 and since 2012, water resources have been abundant (Figure 10c). In G-4, the GWL dropped temporarily to below the 95\% occurrence line in 2007 and in May 2012; since June 2013, the water level has been continuously below the $95 \%$ occurrence line (Figure 10d). In G-5, there was a clear pattern of seasonal water-level fluctuations but there were temporary declines in the GWL. The hydrograph was continually at the bottom of the 95\% occurrence line from August 2008 to February 2009; in 2015, the GWL decreased to below the $95 \%$ occurrence line many times (Figure 10e).
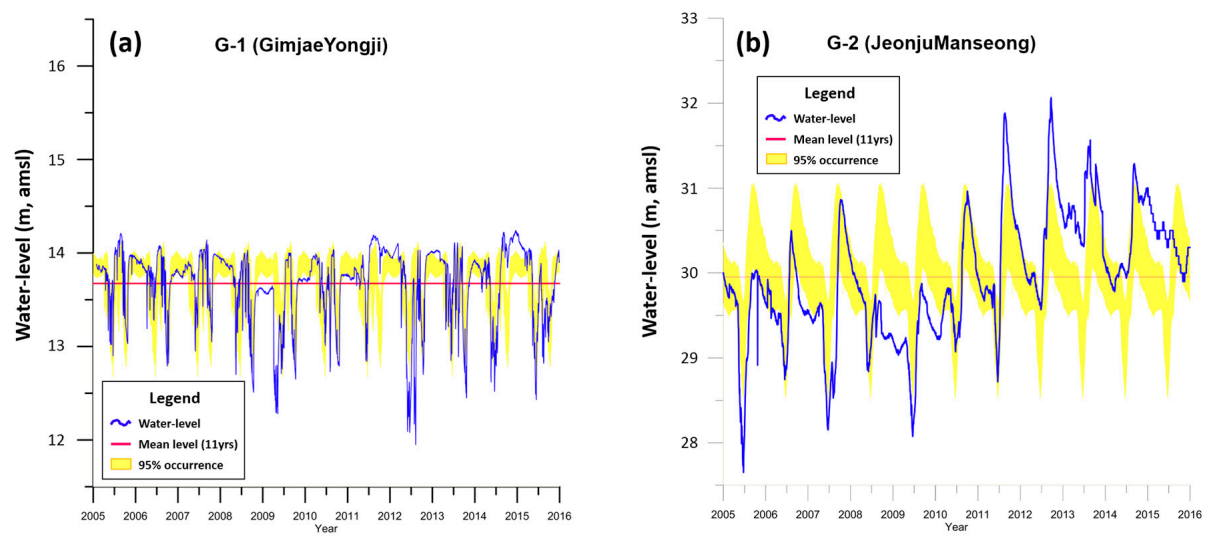

Figure 10. Cont. 

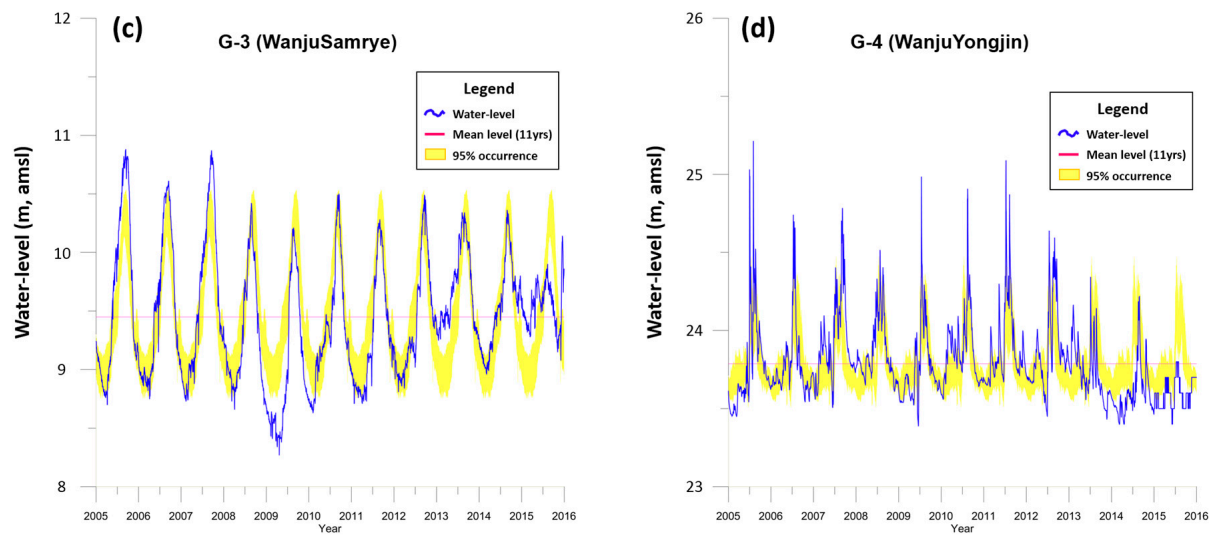

(e)

G-5 (WanjuGosan)

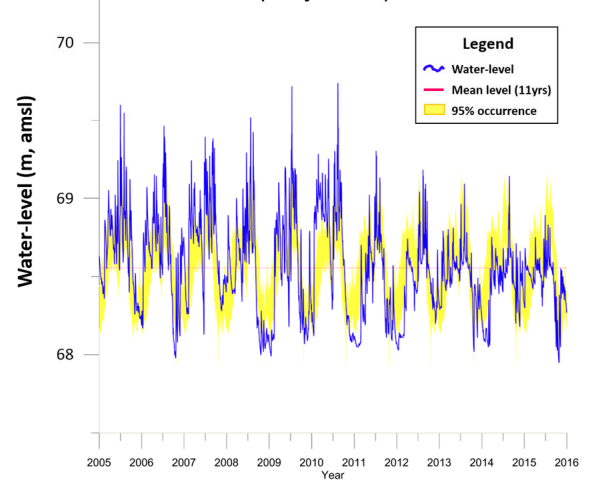

Figure 10. Groundwater fluctuation, the $95 \%$ probability of occurrence line and average groundwater-level (red line) from 2005 to 2015 at (a) G-1, GimjaeYongji; (b) G-2, JeonjuManseong; (c) G-3, WanjuSamrye; (d) G-4, WanjuYongjin; and (e) G-5, WanjuGosan.

There are various drought definitions, drought calculation methods and indices; however, there is no absolute method. It is important to apply appropriate estimation methods, depending on the purpose and area. We attempted to estimate the groundwater drought caused by a lack of precipitation by analyzing the relatively slow groundwater fluctuation among the elements of the hydrological cyclic. Precipitation in Korea has an annual and seasonal cycle, with most of the annual precipitation concentrated in the short, wet season. When the threshold method was used to evaluate groundwater drought, it was difficult to determine if the decrease in the GWL in spring was correlated with the drought event. This was because the threshold level was high due to the rising average GWL during the wet season. The GWL in spring was repeatedly lower due to the seasonal effect.

When a comparison was made with the Korea drought report (Table 5), it was considered that the estimation of drought by assessing the variation of a groundwater hydrograph (i.e., the $95 \%$ occurrence line), including the annual precipitation cycle, produced the best match with actual drought records.

As reported by the Ministry of Construction and Transportation [59], the monthly agricultural water use and monthly rainfall distribution indicate that the use of agricultural water for paddy farming is the highest in May and June (Figure 11a). From October to May, the GWL declines in spring because it is a dry season, with little rainfall. The range of variation in the annual precipitation cycle was estimated by analyzing the pattern of water-level fluctuations for 11 years in the five monitoring wells of the Mangyeong River Basin (Figure 11). 

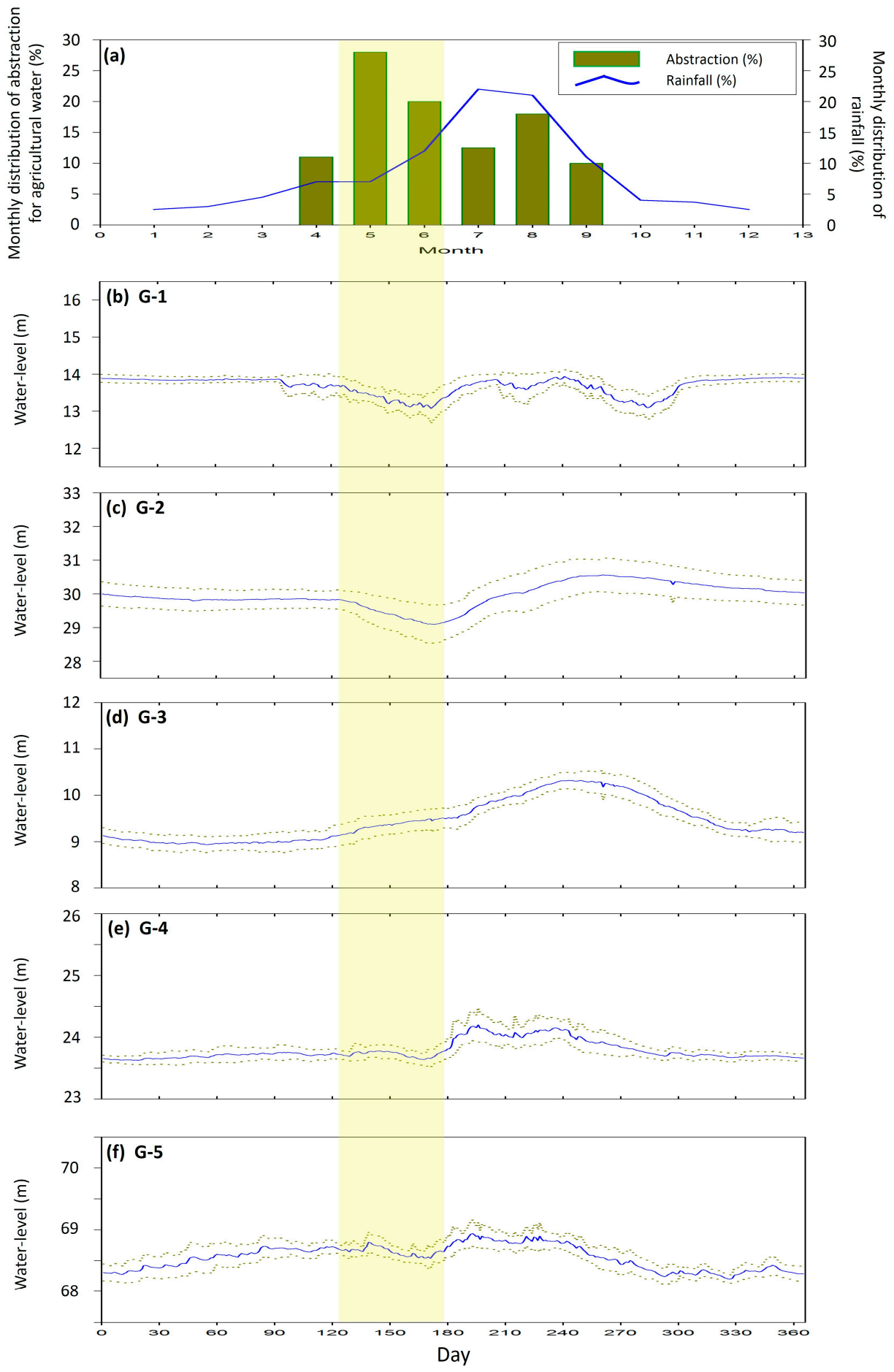

Figure 11. (a) Monthly distribution of rainfall and irrigation water use (upper chart), (b-f) pattern of annual variation and the probability distribution of each groundwater hydrograph for the period of 2005-2015.

The period of GWL decline is consistent with the period of agricultural water use. However, the water-level in the G-3 well varied irrespective of the water-level fluctuations during the farming season. The well is located in the downstream area of the Mangyeong River and had the lowest altitude of wells used in this study. There was no evidence of a declining GWL due to water abstraction for agriculture in this area and the well data indicated a continuous rise in the GWL due to cumulative 
rainfall. Thus, the frequency of occurrence of groundwater drought was the lowest among the five stations studied.

In the G-1 and G-2 monitoring wells, GWL drawdown due to groundwater abstraction was apparent in the spring and the GWLs increased in the rainy season. Because the data acquisition period for groundwater statistics was not long enough, it was impossible to simulate groundwater level fluctuations due to natural discharges through a comparison with nearby stream discharge. In addition, the correlation coefficient for the relationship between precipitation and GWL was not significant and groundwater drought could not be determined due to the lack of rainfall. However, the frequency of occurrence of groundwater drought was 22 and 10 days in G-1 and G-2, respectively and the drought severity was about $1.5 \mathrm{~m}$ lower than the threshold value. The groundwater drought in this area was aggravated by anthropogenic influences. The increased GWL during the rainy season produced an exponential function for the natural discharge after the monsoon period and the slope of the decreasing curve increased sharply due to the effect of groundwater abstraction for agriculture (Figure 12). The greater frequency of droughts compared to the upstream G-4 and G-5 sites indicated that anthropogenic factors could enhance drought and increase the need for water management.

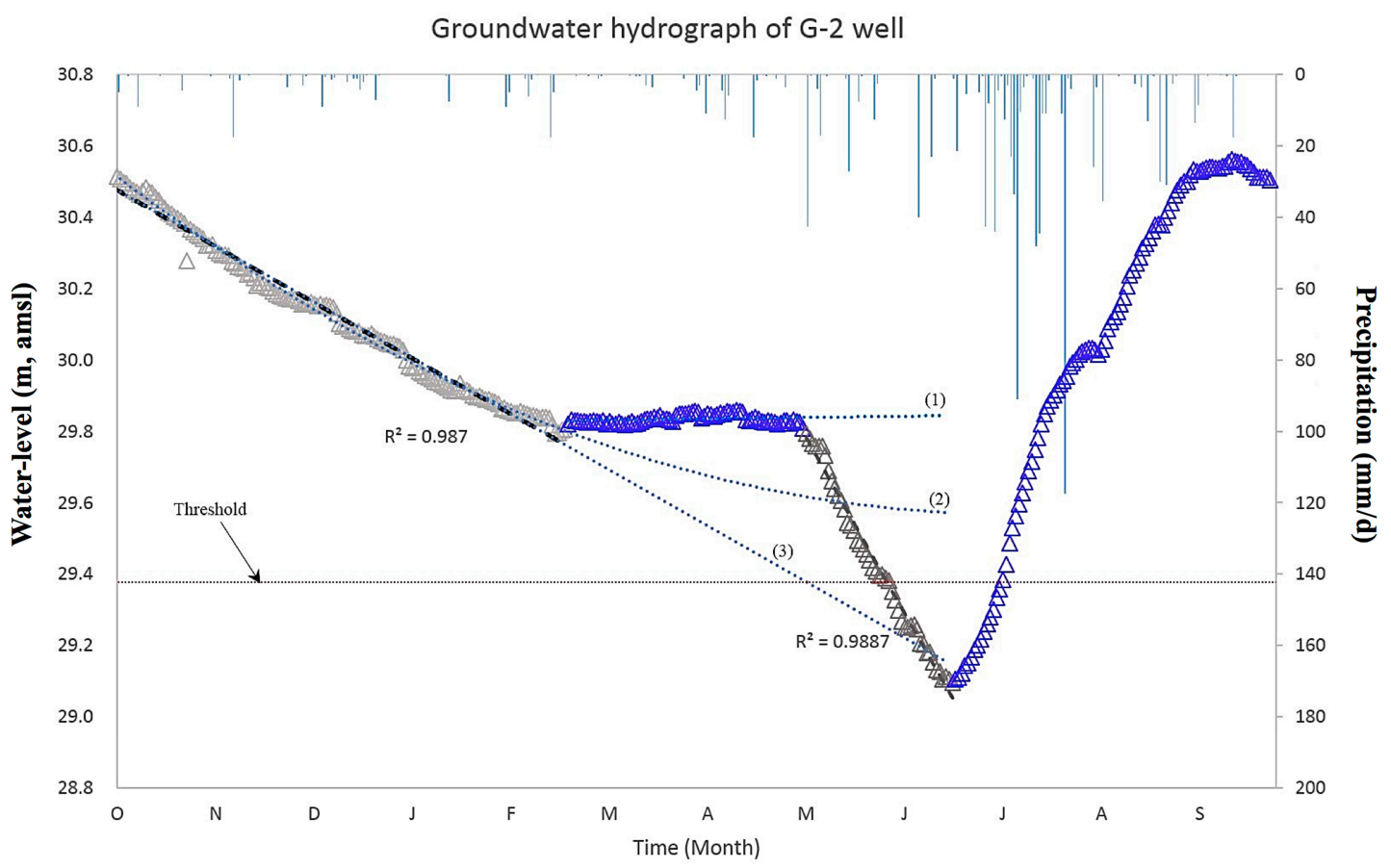

Figure 12. Groundwater hydrograph of the G-2 well showing the annual mean fluctuation of the water-level (from October to September).

Although 2008 and 2014-2015 were reported as severe drought seasons, the river did not dry out. Streamflow was retained in most periods because of the baseflow discharge. The Baseflow Index (BFI) determined by the PART method (using the groundwater toolbox developed by Barlow et al. [60]) indicated that the streamflow was largely caused by groundwater baseflow in most cases, except for high rainfall during the wet season. When the threshold level was reached (when the $c$ value is 0.3 ) in the groundwater drought assessment, the streamflow approached 0 and the BFI reached almost $100 \%$ (Figure 13). This means that the groundwater drought assessment using the threshold method was appropriate and management was required when the GWL reached a threshold level (critical point). 

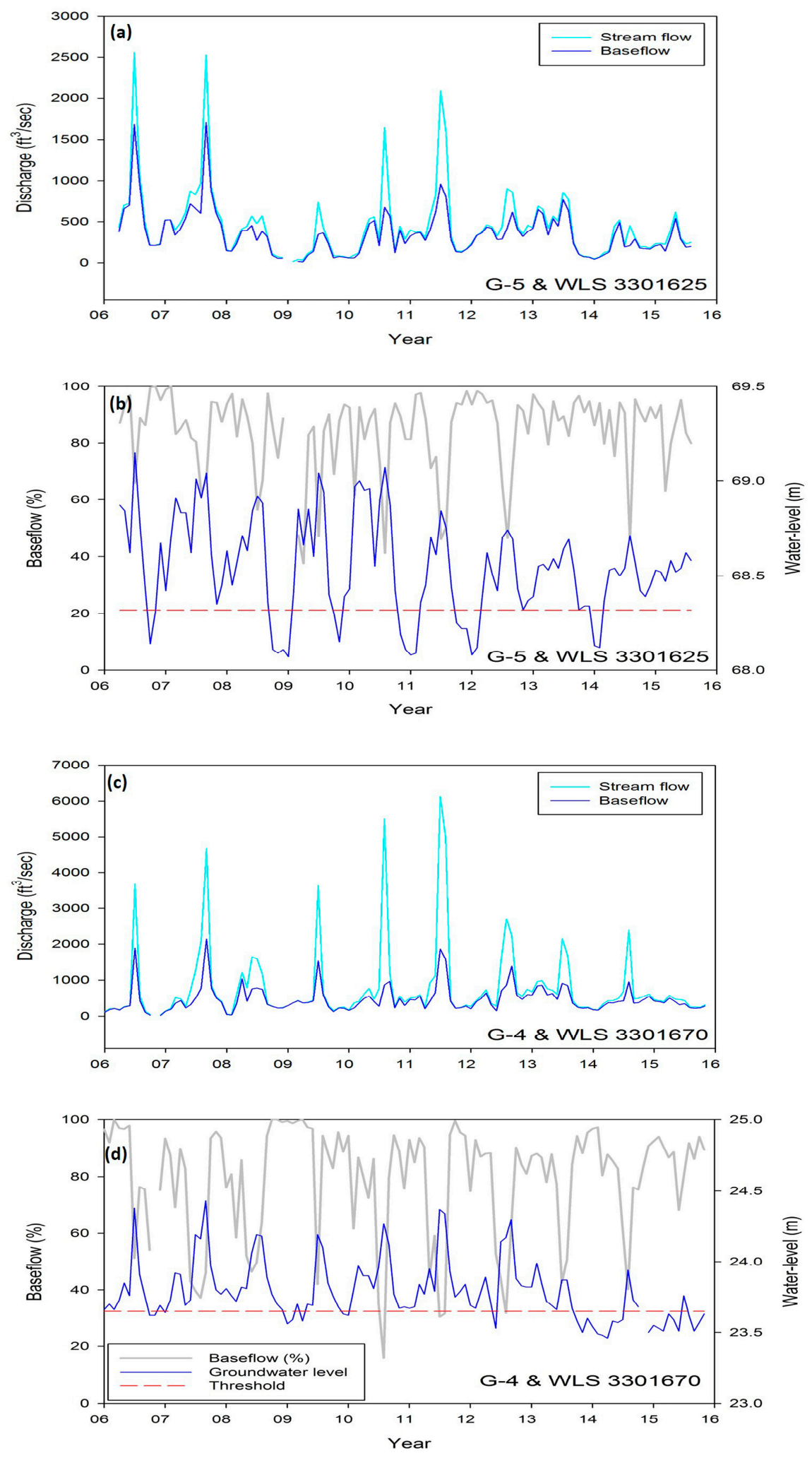

Figure 13. Time-series data of $(\mathbf{a}, \mathbf{c})$ discharge and baseflow; and $(\mathbf{b}, \mathbf{d})$ groundwater fluctuation with the threshold and baseflow index (BFI). 


\section{Conclusions}

To evaluate the groundwater drought in the Mangyeong River Basin, precipitation, surface water (river stage and streamflow at four gauging stations) and groundwater (GWL at five monitoring stations) data for 11 years (2005 to 2015) were analyzed. Correlations were analyzed between rainfall, surface water and groundwater. The SPI index (a commonly used meteorological drought index) was applied to assess groundwater drought using the threshold and the $95 \%$ probability occurrence line methods.

As noted in the drought report, in addition to the weak droughts that occurred every year during the study period, severe droughts occurred in 2008-2009 and 2015, which was consistent with SPI index results. The groundwater drought assessment also indicated that weak droughts occurred annually and a severe drought occurred in 2009; however, in 2015, groundwater drought was only identified in two monitoring wells (G-4 and G-5) located in the upstream area of the study catchment. Due to the monsoon climate, most of the annual rainfall was concentrated in the annual wet season. The GWL decline below the threshold level in June was attributed to the use of agricultural water for farming.

Using the SPI method, threshold method and 95\% probability occurrence line method, each drought detection method and the frequency of drought were compared, as shown in Table 6 . SPI results, which is the most common meteorological drought index for calculating rainfall deviations (in the most recent 30 years), were consistent with the reporting of drought in the study period. When we evaluated the groundwater drought using the threshold method, it was found that drought occurred more frequently than when the SPI method was used. Groundwater droughts were expected to be more sensitive in upstream areas due to hydrogeological features but were more frequent in the downstream. This is evidence that anthropogenic factors can aggravate groundwater droughts. However, when the $c$ (drought criterion) value was applied as 0.1 , droughts were estimated to have a lower frequency than when using the SPI and the results may not be useful for drought prevention. The $95 \%$ occurrence method responds to severe drought but also has a significant disadvantage. The ranges of the $95 \%$ occurrence line calculated from the hydrograph of groundwater level fluctuation cannot be used to evaluate human-induced decreases in the GWL in spring every year due to the deficit of groundwater storage (i.e., groundwater drought). Because it also calculates periodic variations as a probability occurrence range, the drawdown patterns occur repeatedly at the same time every year. Although the groundwater drought index using the threshold method $(c=0.3)$ is not an absolute method, it can include variations of both natural and anthropogenic factors. The threshold method is considered to be a suitable method for predicting severe groundwater drought and for managing water resources in the Mangyeong River Basin.

Table 6. Comparison of the drought events calculated by the standardized precipitation index (SPI) (a meteorological drought index) and the threshold and 95\% probability occurrence methods (groundwater drought indices) for 11 years (2005-2015).

\begin{tabular}{|c|c|c|c|c|c|c|c|c|c|c|c|c|c|c|c|c|c|}
\hline \multirow{3}{*}{ Year } & \multirow{3}{*}{ Month } & \multirow{3}{*}{$\begin{array}{c}\text { SPI } \\
(6-M)\end{array}$} & \multicolumn{15}{|c|}{ Groundwater Drought Methods } \\
\hline & & & \multicolumn{5}{|c|}{ Threshold ( $c$ 0.3) } & \multicolumn{5}{|c|}{ Threshold ( $c$ 0.1) } & \multicolumn{5}{|c|}{ 95\% Occurrence } \\
\hline & & & G-1 & G-2 & G-3 & G-4 & G-5 & G-1 & G-2 & G-3 & G-4 & G-5 & G-1 & G-2 & G-3 & G-4 & G-5 \\
\hline 2006 & October & $\mathrm{O}$ & $\mathrm{O}$ & $\mathrm{O}$ & $\mathrm{O}$ & $\mathrm{O}$ & $\mathrm{O}$ & $\mathrm{O}$ & $\mathrm{O}$ & $\mathrm{O}$ & $x$ & $\mathrm{O}$ & $\mathrm{x}$ & $\mathrm{x}$ & $\mathrm{x}$ & $\mathrm{O}$ & $\mathrm{O}$ \\
\hline 2009 & September-February & $\mathrm{O}$ & $\mathrm{O}$ & $\mathrm{O}$ & $\mathrm{O}$ & $\mathrm{O}$ & $\mathrm{O}$ & $\mathrm{O}$ & $\mathrm{O}$ & $\mathrm{O}$ & $\mathrm{O}$ & $\mathrm{O}$ & $\mathrm{O}$ & $\mathrm{O}$ & $\mathrm{O}$ & $\mathrm{O}$ & $\mathrm{O}$ \\
\hline 2012 & May-June & $\mathrm{O}$ & $\mathrm{O}$ & $\mathrm{x}$ & $\mathrm{O}$ & $\mathrm{O}$ & $\mathrm{O}$ & $\mathrm{O}$ & $\mathrm{x}$ & $x$ & $\mathrm{O}$ & $\mathrm{x}$ & $\mathrm{O}$ & $\mathrm{x}$ & $\mathrm{x}$ & $\mathrm{O}$ & $\mathrm{O}$ \\
\hline 2014 & July & $\mathrm{O}$ & $\mathrm{O}$ & $\mathrm{x}$ & $x$ & $\mathrm{O}$ & $\mathrm{O}$ & $\mathrm{O}$ & $\mathrm{x}$ & $x$ & $\mathrm{O}$ & $\mathrm{x}$ & $\mathrm{x}$ & $\mathrm{x}$ & $\mathrm{x}$ & $\mathrm{O}$ & $\mathrm{O}$ \\
\hline 2015 & August-November & $\mathrm{O}$ & $\mathrm{O}$ & $\mathrm{x}$ & $\mathrm{x}$ & $\mathrm{O}$ & $\mathrm{O}$ & $\mathrm{x}$ & $\mathrm{x}$ & $x$ & $\mathrm{O}$ & $\mathrm{O}$ & $\mathrm{O}$ & $x$ & $x$ & $\mathrm{O}$ & $\mathrm{O}$ \\
\hline \multicolumn{2}{|c|}{$\begin{array}{l}\text { Estimated overall frequency } \\
\text { of drought }\end{array}$} & 11 & 22 & 10 & 9 & 16 & 14 & 14 & 6 & 7 & 12 & 11 & 5 & 4 & 2 & 6 & 7 \\
\hline
\end{tabular}

Groundwater droughts-defined as storage (or water-level) decreases due to both a deficit of precipitation and human impacts-vary depending on the well location, depth, aquifer characteristics and period of time. The GWL data of the G-4 and G-5 wells and the streamflow data of the adjacent 
gauging stations were used to analyze and compare the streamflow, baseflow and the BFI. When we assessed the groundwater drought, if the GWL reached the threshold level (when the $c$ value $=0.3$ ), the streamflow approached zero and the BFI was almost $100 \%$. This means that the streamflow depends on the baseflow during the dry season in the study catchment. It was concluded that the threshold method can provide groundwater drought information and can be used to indicate that management is required when the GWL reaches a threshold level.

Supplementary Materials: The following are available online at http:/ / www.mdpi.com/2071-1050/10/3/831/ s1. Figure S1: Graphical method for recharge using the modified water-table fluctuation method, Figure S2: monitoring data of air temperature and evaporation, Tables S1 and S2: Results of recharge analyses and monitoring data of precipitation.

Acknowledgments: This work was supported by the Korea Meteorological Industry Promotion Agency funded by the Korea Meteorological Administration Research and Development Program under grant "KMIPA 2015-6090" in Korea. The groundwater (NGMS) and precipitation (ASOS) data for this work were obtained from the National Groundwater Information Management and Service Center and the Korea Meteorological Administration, respectively. This paper was published as a part of a Ph.D. thesis from Yonsei University, 2018.

Author Contributions: Jae Min Lee and Nam C. Woo conceived and designed the research and wrote the paper; Jae Min Lee, Euijin Chung and Jong Hoon Park analyzed the data; Jae Min Lee and Jong Hoon Park contributed to collect the raw data.

Conflicts of Interest: The authors declare no conflict of interest.

\section{References}

1. Wright, B.; Stanford, B.D.; Reinert, A.; Routt, J.C.; Khan, S.J.; Debroux, J.F. Managing water quality impacts from drought on drinking water supplies. J. Water Supply Res. Technol. AQUA 2014, 63, 179-188. [CrossRef]

2. Mosley, L.M. Drought impacts on the water quality of freshwater systems: Review and integration. Earth Sci. Rev. 2015, 140, 203-214. [CrossRef]

3. Dahm, C.N.; Baker, M.A.; Moore, D.I.; Thibault, J.R. Coupled biogeochemical and hydrological responses of streams and rivers to drought. Freshw. Biol. 2003, 48, 1219-1231. [CrossRef]

4. Wilhite, D.A.; Glantz, M.H. Understanding the drought phenomenon: The role of definitions. Water Int. 1985, 10, 111-120. [CrossRef]

5. NDMC. Understanding and Defining Drought; National Drought Mitigation Center, University of Nebraska-Lincoln: Lincoln, NE, USA, 1995; Available online: http://drought.unl.edu/ (accessed on 14 September 2017).

6. McKee, T.B.; Doesken, N.J.; Leist, J. The relationship of drought frequency and duration time scales. In Proceedings of the 8th Conference on Applied Climatology, Anaheim, CA, USA, 17-23 January 1993; American Meteorological Society: Boston, MA, USA, 1993; pp. 179-184.

7. Palmer, W.C. Meteorologic Drought; Research Paper, No. 45; U.S. Department of Commerce, Weather Bureau: Washington, DC, USA, 1965; p. 58.

8. Palmer, W.C. Keeping track of crop moisture conditions, nationwide: The new crop moisture index. Weatherwise 1968, 21, 156-161. [CrossRef]

9. Rouse, J.W.; Haas, R.H.; Schell, J.A.; Deering, D.W. Monitoring vegetation systems in the Great Plains with ERTS. In Proceedings of the 3rd Earth Resources Technology Satellite-1 Symposium, Washington, DC, USA, 10-14 December 1973; NASA SP-351 I; National Aeronautics and Space Administration: Washington, DC, USA, 1974; pp. 301-317.

10. Shafer, B.A.; Dezman, L.E. Development of a Surface Water Supply Index (SWSI) to Assess the Severity of Drought Conditions in Snowpack Runoff Areas. In Proceedings of the 50th Annual Meeting, Western Snow Conference, Reno, NV, USA, 19-23 April 1982; Colorado State University: Fort Collins, CO, USA, 1982; pp. 164-175.

11. Jacobi, J.; Perrone, D.; Duncan, L.L.; Hornberger, G. A tool for calculating the Palmer drought indices. Water Resour. Res. 2013, 49, 6086-6089. [CrossRef]

12. Gamvroudis, C.; Dokou, Z.; Nikolaidis, N.P.; Karatzas, G.P. Impacts of surface and groundwater variability response to future climate change scenarios in a large Mediterranean watershed. Environ. Earth Sci. 2017, 76, 385. [CrossRef] 
13. Minning, M.; Moeck, C.; Radny, D.; Schirmer, M. Impact of urbanization on groundwater recharge rates in Dübendorf, Switzerland. J. Hydrol. 2017. [CrossRef]

14. Epting, J.; Scheidler, S.; Affolter, A.; Borer, P.; Mueller, M.H.; Egli, L.; García-Gil, A.; Huggenberger, P. The thermal impact of subsurface building structures on urban groundwater resources-A paradigmatic example. Sci. Total Environ. 2017, 596-597, 87-96. [CrossRef] [PubMed]

15. Liu, F.; Yi, S.; Ma, H.; Huang, J.; Tang, Y.; Qin, J.; Zhou, W.-H. Risk assessment of groundwater environmental contamination: A case study of a karst site for the construction of a fossil power plant. Environ. Sci. Pollut. Res. 2017. [CrossRef] [PubMed]

16. Melchior, P. Earth Tides in Research in Geophysics, 2nd ed.; Odishaw, H., Ed.; Massachusetts Institute of Technology Press: Cambridge, MA, USA, 1964; pp. 183-193.

17. Bredehoeft, J.D. Response of well-aquifer systems to earth tides. J. Geophys. Res. 1967, 72, 3075-3087. [CrossRef]

18. Freeze, R.A.; Cherry, J.A. Groundwater; Prentice Hall: Upper Saddle River, NJ, USA, 1979.

19. George, L.M. Introduction to Physical Oceanography; American Institute of Physics: College Park, MD, USA, 1996.

20. Holman, I.; Rivas-Casado, M.; Bloomfield, J.P.; Gurdak, J.J. Identifying non-stationary groundwater level response to North Atlantic ocean-atmosphere teleconnection patterns using wavelet coherence. Hydrogeol. J. 2011, 19, 1269-1278. [CrossRef]

21. Bloomfield, J.P.; Marchant, B.P. Analysis of groundwater drought building on the standardised precipitation index approach. Hydrol. Earth Syst. Sci. 2013, 17, 4769-4787. [CrossRef]

22. Van Loon, A.F. On the Propagation of Drought: How Climate and Catchment Characteristics Influence Hydrological Drought Development and Recovery. Ph.D. Thesis, Wageningen University, Wageningen, The Netherlands, 2013. Available online: http:/ / edepot.wur.nl/249786 (accessed on 20 September 2017).

23. Zhang, R.R.; Chen, X.; Cheng, Q.B.; Zhang, Z.C.; Shi, P. Joint probability of precipitation and reservoir storage for drought estimation in the headwater basin of the Huaihe River, China. Stoch. Environ. Res. Risk Assess. 2016, 30, 1641-1657. [CrossRef]

24. Hall, F.R. Base Flow Recessions-A Review. Water Resour. Res. 1968, 4, 973-983. [CrossRef]

25. Hayashi, M.; Rosenberry, D.O. Effects of Ground Water Exchange on the Hydrology and Ecology of Surface Water. Groundwater 2002, 40, 309-316. [CrossRef]

26. Bekesi, G.; McGuire, M.; Moiler, D. Groundwater Allocation Using a Groundwater Level Response Management Method-Gnangara Groundwater System, Western Australia. Water Resour. Manag. 2009, 23, 1665-1683. [CrossRef]

27. Martens, K.; Van Camp, M.; Walraevens, K. Quantification of water table dynamics as a reference for impact assessment of ecohydrological enhancement measures in a dune area in Begium. Environ. Earth Sci. 2015, 73, 2223-2240. [CrossRef]

28. Chang, T.J.; Teoh, C.B. Use of the Kriging method for studying characteristics of ground water droughts. J. Am. Water Resour. Assoc. 1995, 257, 1001-1007. [CrossRef]

29. Eltahir, E.A.B.; Yeh, P.J.F. On the asymmetric response of aquifer water level to floods and droughts in Illinois. Water Resour. Res. 1999, 35, 1199-1217. [CrossRef]

30. Van Loon, A.F.; Gleeson, T.; Clark, J.; Van Dijk, A.I.J.M.; Stahl, K.; Hannaford, J.; Di Baldassarre, G.; Teuling, A.J.; Tallaksen, L.M.; Uijlenhoet, R.; et al. Drought in the Anthropocence. Nat. Geosci. 2016, 9, 89-91. [CrossRef]

31. Mishra, A.K.; Singh, V.P. A review of drought concepts. J. Hydrol. 2010, 391, 202-216. [CrossRef]

32. Marsh, T.J.; Monkhouse, R.A.; Arnell, N.W.; Lees, M.L.; Reynard, N.S. The 1988-92 Drought; Institute of Hydrology: Wallingford, UK, 1994.

33. Peters, E.; Van Lanen, H.A.J.; Bradford, R.B.; de Abia, J.C.; Martinez Cortina, L. Droughts derived from groundwater heads and groundwater discharge. In Assessment of the Regional Impact of Droughts in Europe; Final Report to the European Union; Institute of Hydrology, University of Freiburg: Breisgau, Germany, 2001; pp. 35-39.

34. Mendicino, G.; Senatore, A.; Versace, P. A Groundwater Resource Index (GRI) from drought monitoring and forecasting in a Mediterranean climate. J. Hydrol. 2008, 357, 282-302. [CrossRef]

35. Ben-Zvi, A. Indices of hydrological drought in Israel. J. Hydrol. 1987, 92, 179-191. [CrossRef] 
36. Nalbantis, I.; Tsakiris, G. Assessment of Hydrological Drought Revisited. Water Resour. Manag. 2009, 23, 881-897. [CrossRef]

37. Ministry of Land, Transport and Maritime Affairs (MLTM). Mangyeong River Basic Plan (Supplementation) Report; MLTM: Sejong, Korea, 2012. (In Korean)

38. Wilhite, D.A. Drought: A Global Assessment; Routledge Hazards and Disasters Series; Routledge: London, UK, 2000; Volume I-II.

39. Hisdal, H.; Tallaksen, L.M.; Clausen, B.; Peters, E.; Gustard, A. Hydrological Drought Processes and Estimation Methods for Streamflow and Groundwater; Developments in Water Science 48; Elsevier Science B.V.: Amsterdam, The Netherlands, 2004; Chapter 5, pp. 139-198.

40. Hisdal, H.; Tallaksen, L.M. Drought Event Definition; ARIDE Technical Report No. 6; University of Oslo: Oslo, Norway, 2000.

41. Peters, E. Propagation of Drought through Groundwater Systems: Illustrated in the Pang (UK) and Upper-Guadiana (ES) Catchment. Ph.D. Thesis, Wageningen University, Wageningen, The Netherlands, 2003.

42. Box, G.E.P.; Jenkins, G.M. Time Series Analysis: Forecasting and Control; Holden-Day: San Francisco, CA, USA, 1976.

43. Davis, J.C. Statistics and Data Analysis in Geology, 2nd ed.; Wiley: New York, NY, USA, 1986.

44. Mayaud, C.; Wagner, T.; Benischke, R.; Birk, S. Single event time series analysis in a binary karst catchment evaluated using a groundwater model (Lurbach system, Austria). J. Hydrol. 2014, 511, 628-639. [CrossRef] [PubMed]

45. Laricque, M.; Mangin, A.; Razack, M.; Banton, O. Contribution of Correlation and Spectral Analysis to the Regional Study of a Large Karst Aquifer (Charente, France). J. Hydrol. 1998, 5, 217-231. [CrossRef]

46. Wanders, N.; Van Lanen, H.A.J.; Van Loon, A.F. Indicators for Drought Characterization on a Global Scale; WATCH Technical Report, No. 24; Wageningen University: Wageningen, The Netherlands, 2010.

47. Sheffield, J.; Wood, E.F. Drought: Past Problems and Future Scenarios; Routledge, Taylor and Francis: New York, NY, USA, 2011.

48. WMO. Standardized Precipitation Index User Guide; WMO-No. 1090; Svoboda, M., Hayes, M., Wood, D., Eds.; WMO: Geneva, Switzerland, 2012.

49. Van Lanen, H.A.J.; Peters, E. Definition, Effects and Assessment of Groundwater Droughts. In Drought and Drought Mitigation in Europe; Vogt, J.V., Somma, F., Eds.; Advances in Natural and Technological Hazards Research; Springer: Dordrecht, The Netherlands, 2000; pp. 49-61.

50. Calow, R.; Robins, N.; Macdonald, A.; Nicol, A. Planning for groundwater drought in Africa. In Proceedings of the International Conference on Integrated Drought Management: Lessons for Sub-Saharan Africa, Pretoria, South Africa, 20-22 September 1999; IHP-V, Technical Documents in Hydrology, No. 35. pp. 255-270.

51. Yevjevich, V. An Objective Approach to Definitions and Investigations of Continental Hydrologic Droughts; Hydrology Papers; Colorado State University: Fort Collins, CO, USA, 1967; Volume 23.

52. Tallaksen, L.M.; Madsen, H.; Clausen, B. On the definition and modelling of streamflow drought duration and deficit volume. Hydrol. Sci. J. 1997, 42, 15-33. [CrossRef]

53. Peters, E.; Torfs, P.J.J.F.; Van Lanen, H.A.J.; Bier, G. Propagation of drought through groundwater-A new approach using linear reservoir theory. Hydrol. Process. 2003, 17, 3023-3040. [CrossRef]

54. Peters, E.; Van Lanen, H.A.J.; Torfs, P.J.J.F.; Bier, G. Drought in groundwater-drought distribution and performance indicators. J. Hydrol. 2005, 306, 302-317. [CrossRef]

55. Van Lanen, H.A.J.; Kundzewicz, Z.W.; Tallaksen, L.M.; Hisdal, H.; Fendeková, M.; Prudhomme, C. Indices for Different Types of Droughts and Floods at Different Scales; Water and Global Change; Centre for Ecology and Hydrology: Wallingford, UK, 2008.

56. Ha, K.; Ko, K.S.; Koh, D.C.; Yum, B.W.; Lee, K.K. Time Series Analysis of the Responses of the Groundwater Levels at Multi-depth Wells according to the River Stage Fluctuations. Econ. Environ. Geol. 2006, 39, $269-284$. (In Korean)

57. Lee, J.M.; Woo, N.C.; Lee, C.J.; Yoo, K.J. Characterising Bedrock Aquifer Systems in Korea Using Paired Water-Level Monitoring Data. Water 2017, 9, 420. [CrossRef]

58. Van Loon, A.F.; Van Lanen, H.A.J. Making the distribution between water scarcity and drought using an observation-modeling framework. Water Resour. Res. 2013, 49, 1483-1502. [CrossRef] 
59. Ministry of Construction and Transportation (MOCT). A Report on Estimation of Instream Flow and River in the Han River Basin; MOCT: Seoul, Korea, 1998. (In Korean)

60. Barlow, P.M.; Cunningham, W.L.; Zhai, T.; Gray, M. U.S. Geological Survey Groundwater Toolbox, a Graphical and Mapping Interface for Analysis of Hydrologic Data (Version 1.0)_User Guide for Estimation of Base Flow, Runoff, and Groundwater Recharge from Streamflow Data; U.S. Geological Survey Techniques and Methods, Book 3; U.S. Geological Survey: Reston, VA, USA, 2015; Chapter B10; 27p. Available online: http:/ / dx.doi.org/10. $3133 / \mathrm{tm} 3 \mathrm{~B} 10$ (accessed on 2 October 2017). 